\title{
Article
}

\section{Chemical, microbiological and volatile composition of kefir- like beverages produced from red table grape juice in repeated 24-h fed-batch subcultures}

\author{
Delicia L. Bazán ${ }^{1,2}$, Pablo G. del Río³, José M. Domínguez, Sandra Cortés ${ }^{4}$, Juan Carlos Mejuto5,* Nelson Pérez- \\ Guerra $^{2}$
}

1 Academic Department of Food Industries Engineering. Engineering Faculty, National University of Jaén, Jr. Cuzco 250, Pueblo Libre, Jaén, Cajamarca, Perú.

2 Department of Analytical and Food Chemistry. Food Science Faculty, University of Vigo, Ourense Campus, As Lagoas s/n, 32004, Ourense, Spain.

3 Department of Chemical Engineering. Food Science Faculty, University of Vigo Ourense Campus, As Lagoas s/n, 32004, Ourense, Spain.

4 Industrial Biotechnology and Environmental Engineering Group "BiotecnIA", Chemical Engineering Department, University of Vigo (Campus Ourense), As Lagoas s/n, 32004, Ourense, Spain.

5 Department of Physical Chemistry. Faculty of Sciences, Ourense Campus, University of Vigo, As Lagoas s/n, 32004 Ourense, Spain

* Correspondence: xmejuto@uvigo.es (J.C.M.); Tel.: +34-88-387-031

\begin{abstract}
The aim of this work was to study the production of kefir-like beverage by fed-batch fermentation of red table grape juice at initial pHs of 3.99 (fermentation A) and 5.99 (fermentation B) with kefir grains during four repeated $24-\mathrm{h}$ fed-batch subcultures. However, all kefir-like beverages $(\mathrm{KLB})$ were characterized by low alcoholic grade $(\leq 3.6 \%, \mathrm{v} / \mathrm{v})$ and lactic and acetic acid concentrations. The beverages obtained from fermentation $B$ had lower concentrations of sugars and higher microbial counts than the KLB obtained in fermentation A. In addition, the KLB from fermentation $B$ were the most aromatic and had the highest contents in alcohols, esters, aldehydes and organic acids compared to the non-fermented juice and KLB from fermentation A. These results indicate the possibility of obtaining red table grapes KLB with their own distinctive aromatic characteristics and a high content in probiotic viable cells, contributing to the valorization of this fruit.
\end{abstract}

Keywords: kefir grains, red table grapes, kefir-like beverage, fed-batch fermentation, volatile compounds

\section{Introduction}

Nowadays, there is an increasing interest of consumers for healthier ecological and functional foods, containing biologically active components, due to the development of knowledge about the potential positive health effects produced by these foods. [1]

Kefir is a refreshing, creamy and slightly carbonated drink with a low level of ethanol and acetic acid, a slight acid or bitter taste and a mild aroma similar to fresh yeast. [2] This drink is obtained from fermentation of milk with kefir grains, which mainly contain lactic acid bacteria ( $\mathrm{LAB})$, acetic acid bacteria $(\mathrm{AAB})$ and yeasts that grow in symbiosis and are held together by a matrix of proteins and a polysaccharide composed of glucose and galactose units, known as kefiran. [3,4] The final $\mathrm{pH}$ of kefir normally ranges between 4.3 and 4.4, due to the production of lactic acid by LAB from lactose. The content of lactic acid, ethanol and $\mathrm{CO}_{2}$ is controlled by the incubation temperature during the production process. [5] 
Kefir has high nutritional value and health-improving properties, which are associated with the presence in this drink, of a high concentration of viable probiotic microorganisms (LAB, AAB and yeasts) and fermentation products including kefiran, enzymes ( $\beta$-galactosidase), organic acids and volatile compounds. [6] Thus, according to different researchers, consumption of kefir: i) allows to improve the tolerance and digestion of lactose in lactose intolerant individuals, [7] ii) helps to treat tuberculosis, obesity, constipation, disease inflammatory bowel disease, allergies, and even cancer, and iii) controls the increase in blood pressure and reduces cholesterol levels serum. [8]

Recently, different nondairy substrates have been assayed to produce potentially probiotic kefir-like beverages with a high content in probiotic strains, including molasses and coconut, [9] cocoa pulp, [10] and more recently, juices extracted from carrot, fennel, melon, onion, tomato and strawberry, [11] apple, grape, kiwifruit, pomegranate, prickly pear and quince. [12]

The grape fruit contains various nutrients such as vitamins, minerals, carbohydrates, edible fibers and phytochemicals. Polyphenols are the most important phytochemicals present in grapes because of their biological activity and potential health effects, including the inhibition of some degenerative diseases, such as cardiovascular diseases [13] and some types of cancer. [14,15] These compounds also slow down aging [16] and have a preservative effect on the oxidation of food. [17]

Considering the beneficial effects of kefir beverages and grapes, the heterogeneity of substrates that can be fermented by the kefir grains and the gradual reduction in the consumption of table grapes in Spain in recent years, [18] the use of this fruit as a substrate for obtaining a potentially probiotic beverage, is an interesting alternative that could contribute to the valorization of table grapes. In addition, this approach could also contribute to increase the Spanish producer income. The current marketing of fermented beverages from grapes could facilitate the commercialization of the kefir-like beverages from red table grapes.

Since in pure cultures of $\mathrm{LAB}$, the use of the fed-batch fermentation modality allowed to improve the biomass production, [9,19-20] the use of this fermentation procedure to produce a kefir-like beverage from table grape juice with kefir grains could offer the possibility of obtaining a drink with a high concentration of probiotic cells.

However, there is no information available on the kinetics of the batch or fed-batch fermentation of red table grapes with milk kefir grains.

Taking into account these considerations, this work aimed to study the kinetics of fed-batch fermentation of red table grape juice with kefir grains and characterize both qualitatively and quantitatively the chemical, microbiological and volatile compositions of the beverages obtained. Given the difference in the optimal level of $\mathrm{pH}$ for lactic acid bacteria $(\mathrm{LAB})$, acetic bacteria $(\mathrm{AAB})$ and yeast present in the kefir grains, two fermentations (at initial $\mathrm{pH}$ values 3.99 ( $\mathrm{pH}$ of the red table grape juice) and 5.99) were developed to study the effect of this variable on the chemical, microbiological and volatile composition of the kefir-like beverages obtained.

\section{Results and Discussion}

\subsection{Fed-Batch Fermentation of Red Table Grapes Juice (initial pH 3.99) with Kefir Grains.}

The fermentation kinetics of red table grape juice with kefir grains in four repeated 24-h fed-batch subcultures is shown in Figure 1. From the detailed observation of the culture, it could be noted that the culture $\mathrm{pH}$ in every subculture decreased slightly, probably due to the low initial pH level (3.99) of the juice and the decrease in the production of organic acids. In fact, the highest concentrations of lactic, acetic, succinic and malic acids $(2.32,3.16,1.92$, and $0.51 \mathrm{~g} / \mathrm{L})$ were obtained in the first subculture, suggesting that the microbial cells from kefir grains progressively lost their ability to acidify the culture medium with the increase in the number of subcultures. 
This gradual decrease in the concentrations of organic acids did not seem to be related to a reduction in the counts of lactic acid bacteria (LAB), acetic acid bacteria (AAB) and yeasts because this only occurs in the four subculture: IV-3.99 (Table 1).

Table 1. Microbial Counts (Log CFU/mL) in the Red Table Grape Juice (RTGJ) and Fermented Beverages obtained from the Four Subcultures in Fed-batch Fermentation A (I-3.99, II-3.99, III-3.99, and IV-3.99) and B (I-5.99, II-5.99, III-5.99, and IV-5.99). Results are shown as Means \pm Standard Deviations of Two Experiments and Three Analytical Replications Each.

\begin{tabular}{|c|c|c|c|c|c|c|c|}
\hline Beverage & $\operatorname{rod} \mathrm{LAB}$ & Mesophilic coccus LAB & Total mesophilic & Enterobacteriaceae & Pseudomonas & $\mathrm{AAB}$ & Yeasts \\
\hline RTGJ & $2.2 \pm 0.1^{\mathrm{a}}$ & $3.2 \pm 0.1^{\mathrm{a}}$ & $3.3 \pm 0.2^{\mathrm{a}}$ & $0.7 \pm 0.1^{\mathrm{a}}$ & $0.5 \pm 0.1^{\mathrm{a}}$ & $2.0 \pm 0.3^{\mathrm{a}}$ & $2.3 \pm 0.3^{\mathrm{a}}$ \\
\hline I-3.99 & $6.0 \pm 0.4^{\mathrm{b}}$ & $6.0 \pm 0.3^{\mathrm{b}}$ & $6.0 \pm 0.7^{\mathrm{b}}$ & $0.3 \pm 0.1^{\mathrm{b}}$ & $0.3 \pm 0.1^{\mathrm{b}}$ & $5.8 \pm 0.1^{b}$ & $7.9 \pm 0.1^{b}$ \\
\hline II-3.99 & $6.5 \pm 0.3^{\mathrm{c}}$ & $6.5 \pm 0.3^{\mathrm{c}}$ & $6.5 \pm 0.5^{\mathrm{c}}$ & $0.3 \pm 0.1^{\mathrm{b}}$ & $0.3 \pm 0.1^{\mathrm{b}}$ & $6.0 \pm 0.5^{\mathrm{c}, \mathrm{b}}$ & $8.0 \pm 0.7^{\mathrm{c}, \mathrm{b}}$ \\
\hline III-3.99 & $6.6 \pm 0.3^{\mathrm{d}, \mathrm{c}}$ & $6.7 \pm 0.2^{\mathrm{d}, \mathrm{c}}$ & $6.6 \pm 0.4^{\mathrm{d}, \mathrm{c}}$ & nd & nd & $5.9 \pm 0.3^{\mathrm{d}, \mathrm{b}, \mathrm{c}}$ & $7.9 \pm 0.5^{\mathrm{d}, \mathrm{b}, \mathrm{c}}$ \\
\hline IV-3.99 & $5.6 \pm 0.2^{\mathrm{e}}$ & $5.7 \pm 0.3^{\mathrm{e}, \mathrm{b}}$ & $5.7 \pm 0.1^{\mathrm{e}}$ & $0.3 \pm 0.1^{\mathrm{b}}$ & nd & $5.0 \pm 0.4^{\mathrm{e}}$ & $6.0 \pm 0.6^{\mathrm{e}}$ \\
\hline I-5.99 & $6.9 \pm 0.4^{\mathrm{f}}$ & $6.9 \pm 0.3^{\mathrm{f}, \mathrm{c}, \mathrm{d}}$ & $6.9 \pm 0.7^{\mathrm{f}, \mathrm{c}}$ & $0.3 \pm 0.1^{\mathrm{b}}$ & $0.3 \pm 0.1^{\mathrm{b}}$ & $6.9 \pm 0.7^{\mathrm{f}}$ & $7.6 \pm 0.9^{\mathrm{f}, \mathrm{b}, \mathrm{c}, \mathrm{d}}$ \\
\hline II-5.99 & $8.3 \pm 0.5^{\mathrm{g}}$ & $8.4 \pm 0.4^{\mathrm{g}}$ & $8.4 \pm 0.2^{\mathrm{g}}$ & $0.3 \pm 0.1^{\mathrm{b}}$ & nd & $7.3 \pm 0.5^{\mathrm{g}}$ & $8.3 \pm 0.2^{\mathrm{g}, \mathrm{c}, \mathrm{d}, \mathrm{f}}$ \\
\hline III-5.99 & $8.2 \pm 0.4^{\mathrm{h}, \mathrm{g}}$ & $8.3 \pm 0.3^{\mathrm{h}, \mathrm{g}}$ & $8.3 \pm 0.3^{\mathrm{h}, \mathrm{g}}$ & nd & nd & $7.2 \pm 0.3^{\mathrm{h}, \mathrm{f}, \mathrm{g}}$ & $8.2 \pm 0.5^{\mathrm{h}, \mathrm{b}, \mathrm{c}, \mathrm{d}, \mathrm{f}, \mathrm{g}}$ \\
\hline IV-6.99 & $7.3 \pm 0.3^{\mathrm{i}, \mathrm{f}}$ & $7.3 \pm 0.5^{\mathrm{i}, \mathrm{f}}$ & $7.2 \pm 0.3^{\mathrm{i}, \mathrm{f}}$ & nd & $0.3 \pm 0.1^{\mathrm{b}}$ & $7.1 \pm 0.6^{\mathrm{i}, \mathrm{fg}, \mathrm{h}}$ & $8.2 \pm 0.3^{\mathrm{i}, \mathrm{c}, \mathrm{d}, \mathrm{f}, \mathrm{g}, \mathrm{h}}$ \\
\hline
\end{tabular}

Mean values within columns followed by the same letter are not significantly different by Ryan-Gabriel-Welsch Multiple F-test $(P=0.05)$ after a significant ANOVA $(P<0.05)$.

Thus, it seems more adequate to suppose that the reduction in the concentration of organic acids was due to their consumption by LAB (e.g. L. lactis or Lactobacillus sp.) or non-lactose-consuming yeasts (e.g. Torulaspora delbruekii and Saccharomyces cerevisiae) present in the kefir grains..$^{21}$ In this way, other researchers have observed that some strains of Lb. buchneri and Lb. parabuchneri are capable of degrading lactic acid to produce 0.5 mole of acetic acid, 0.5 mole of propane-1,2-diol, and traces of ethanol.22 In fermentations developed with mixed cultures of Lb. kefiranofaciens and S. cerevisiae, it was observed that lactic acid produced by the lactic acid bacterium was assimilated by yeast. ${ }^{21,23-24}$ The results obtained by Felipe et al..$^{25}$ showed that some species of yeasts of the kefir grains (e.g. Candida guilliermondii) can assimilate in a joint way acetic acid (at concentrations lower than $3.0 \mathrm{~g} / \mathrm{L}$ ) and xylitol from the culture medium. It has also been reported that S. cerevisiae strains can use acetic acid and lactic acid ${ }^{26}$ or citric acid as carbon sources, and non-Saccharomyces yeasts (e.g. Candida sp.) can consume malic acid. ${ }^{27}$ Both malic and citric acids can also be metabolized by LAB. ${ }^{27}$ However, the concentration of tartaric acid slowly decreases, probably due to low consumption of LAB because yeasts lack the biochemical pathway for the degradation of this acid. ${ }^{27}$

This consumption of organic acids produced a gradual reduction in their concentration in the fermentation medium, and consequently, the $\mathrm{pH}$ drop rate decreased progressively in the different subcultures (Fig. 1).

Additionally, the concentration of free biomass (from the kefir grains and the autochthonous biomass of the juice) obtained in the first 24 -h subculture $(5.62 \pm 0.07 \mathrm{~g} / \mathrm{L})$ increased in the second and third subcultures to $11.31 \pm 0.26(48 \mathrm{~h})$ and $11.45 \pm 0.95 \mathrm{~g} / \mathrm{L}(72$ h), but decreased to $6.19 \pm 0.04 \mathrm{~g} / \mathrm{L}$ in the last subculture. The increase in free biomass production in the subcultures II and III $(P<0.05)$ paralleled the increase in the sugars (glucose and fructose) consumption in these two fermentation cycles (Fig. 1). This observation suggests that in subcultures II and III, the microorganisms of the kefir grains were more adapted to the composition and low $\mathrm{pH}$ (3.99) of red grape juice, which were different from the whole milk, the substrate used for kefir grains activation. The observed decrease in biomass production in the subculture IV $(72-96 \mathrm{~h}$ ) could be due to a reduction in the metabolic activity of the microbial population of the kefir grains (Fig. 1). The latter hypothesis is based on the fact that, in the subculture IV, the microbial population of the 
kefir grains also lost its capacity to decrease the culture $\mathrm{pH}$, and the consumption of sugars (glucose and fructose) and synthesis of fermentation products (ethanol, glycerol and organic acids) slowed down (Fig. 1).
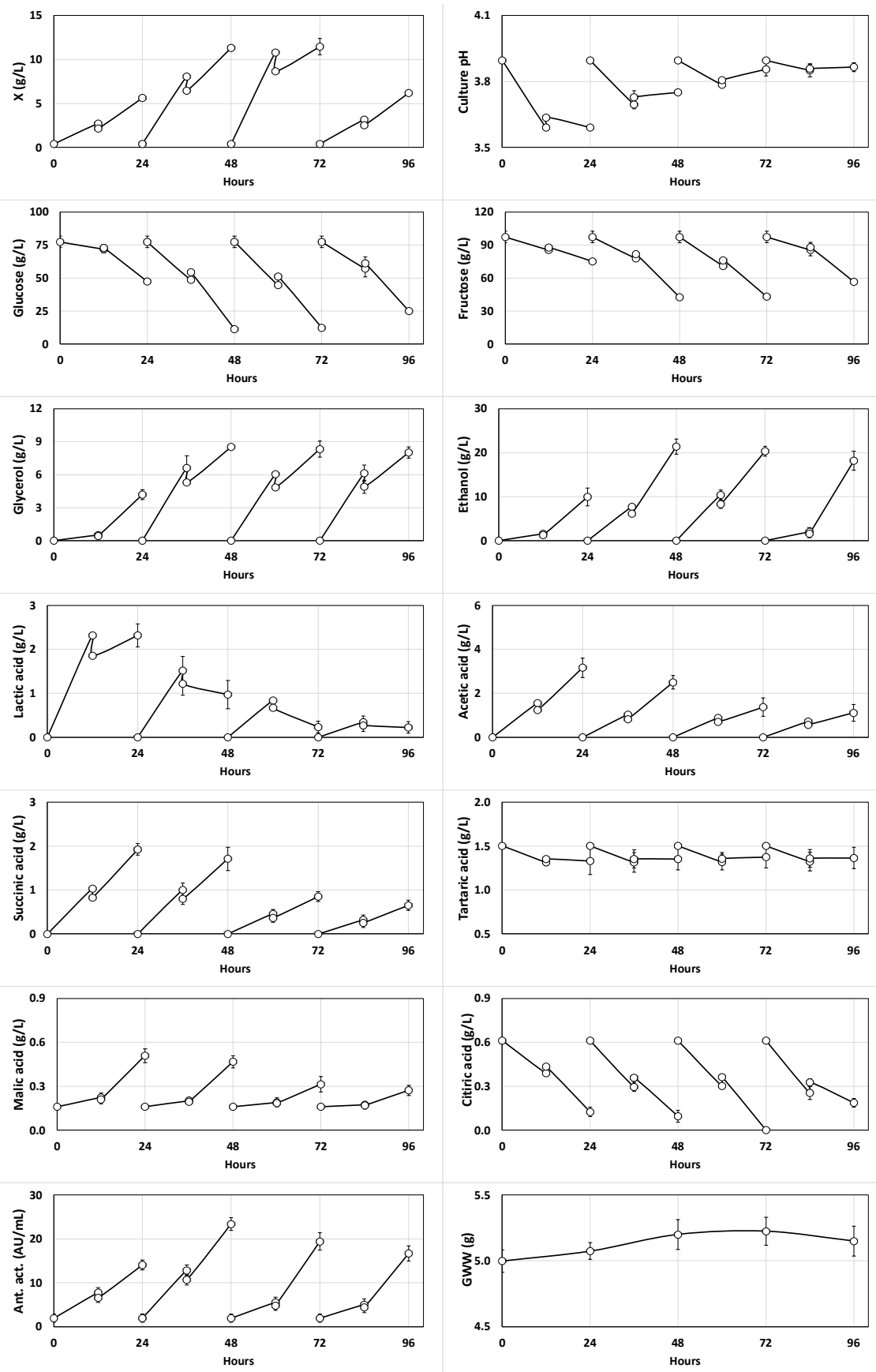

Figure 1. Kinetics of growth $(\mathrm{X})$, culture $\mathrm{pH}$, glucose, fructose, alcohols (glycerol and ethanol), and organic acids (lactic, succinic, tartaric, malic and citric), antibacterial activity (Ant. act.) and grain wet weight $(\mathrm{GWW})$ in the 24-h fed-batch subcultures of red table grapes juice at initial $\mathrm{pH}$ 3.99 fermented with kefir grains. The different subcultures were fed with fresh juice at 12, 36, 60, and $84 \mathrm{~h}$, respectively.

The production of ethanol and glycerol, probably produced by the yeasts of the kefir grains, ${ }^{28-29}$ increased until the third subculture, decreasing slightly in the fourth one (Fig. 1), in parallel with the above-mentioned reduction in the metabolic activity of the strains 
of the kefir grain. However, the antibacterial activity, which is due to the production of bacteriocins by $\mathrm{LAB}^{19}$ and other antimicrobial products (organic acids and alcohols), increased until the second subculture $(23.4 \mathrm{AU} / \mathrm{mL})$ but decreased in the following subcultures to 19.4 and $16.7 \mathrm{AU} / \mathrm{mL}$.

Considering that the objective of this paper was to produce a functional drink with a high content of probiotic biomass nonadhered to grains, the growth of the viable population in the culture medium has great importance. In this case, the counts of $\mathrm{LAB}, \mathrm{AAB}$ and yeasts (in $\log \mathrm{CFU} / \mathrm{mL})$ in each subculture were almost similar $(P>0.05)$ or higher $(P<$ 0.05 ) than $6.0-\log _{10}$ (Table 1 ), which is the concentration of viable probiotic cells needed to observe beneficial physiological effects in the host entity according to Lee et al. ${ }^{30}$ In addition, the Enterobacteriaciae and Pseudomonas counts in both the juice and different beverages were considerably low (Table 1 ) indicating a good hygienic quality of these beverages.

Interestingly, at the end of the four subcultures, both the LAB and yeasts counts were higher $(P<0.05)$ than the AAB counts (Table 1$)$, probably due to a better adaptation of the first two microbial groups to the acidity of the juice of red grapes $(\mathrm{pH}=3.99)$. Although it has been indicated that low $\mathrm{pH}$ levels can inhibit the production of organic acids by LAB and $\mathrm{AAB}$ of the kefir grains, ${ }^{31}$ other researchers have observed that some species of Lactobacillus $^{32}$ and Lactococcus ${ }^{333}$ can grow at $\mathrm{pH}$ levels lower than 3.99. In the case of yeasts, it has been reported that the optimum $\mathrm{pH}$ level for biomass production by Zygosaccharomyces rouxii DSM 70540 was between 3.50 and 5.00, ${ }^{34}$ while for S. cerevisiae T73, S. kudriavzevii W27 and the hybrid interspecific strain of them, S. kudriavzevii IFO 1802T, were respectively $4.76,3.80$, and $4.76 .{ }^{35}$ All these observations suggest that the strains present in the kefir grains can grow at the low $\mathrm{pH}$ value of the red table grape juice.

The wet weight of the kefir grains increased significantly $(P<0.05)$ from $5.00 \mathrm{~g}$ (mass used as inoculum) up to $5.15,5.40$, and $5.40 \mathrm{~g}$ (after 24,48 , and $72 \mathrm{~h}$ of incubation, respectively), but decreased slightly to $5.30 \mathrm{~g}$ in the four subculture (Fig. 1). The increase in the grain weight has been related to the increase in the number of cells that remain anchored to the grain during fermentation, and the increase in the grain matrix weight due to kefiran production. ${ }^{36}$

However, in the fermentation of red table grape juice, the increase in the wet grain weight in the first three subcultures did not seem to be related to kefiran production. This is mainly because this polysaccharide is produced when kefir grains grow on lactose-containing substrates, which provide the two carbon sources (glucose and galactose) present in kefiran. ${ }^{4,36}$

To determine whether the increase in grain weight could be related to the increase in the number of cells that remain anchored to the grain during fermentation, counts of viable $\mathrm{LAB}, \mathrm{AAB}$ and yeasts in the kefir grains were measured after each subculture.

Table 2. Counts of Lactic Acid Bacteria (LAB), Acetic Acid Bacteria (AAB) and Yeasts in the Kefir Grains before Inoculation $(\mathrm{t}=0 \mathrm{~h}$ ) and after 24, 48, 72, and $96 \mathrm{~h}$. Results are shown as Means \pm Standard Deviations of Two Experiments and Three Analytical Replications Each.

\begin{tabular}{lccccc}
\hline & Before inoculation & At $24 \mathrm{~h}$ & At $48 \mathrm{~h}$ & At $72 \mathrm{~h}$ & At $96 \mathrm{~h}$ \\
\hline $\mathrm{LAB}(\mathrm{CFU} / \mathrm{g})$ & $9.9 \pm 1.3 \times 10^{7}$ & $9.6 \pm 1.5 \times 10^{7}$ & $9.5 \pm 1.4 \times 10^{7}$ & $9.2 \pm 1.7 \times 10^{7}$ & $9.0 \pm 1.4 \times 10^{7}$ \\
$\mathrm{AAB}(\mathrm{CFU} / \mathrm{g})$ & $6.8 \pm 1.0 \times 10^{6}$ & $6.6 \pm 1.2 \times 10^{6}$ & $6.5 \pm 1.2 \times 10^{6}$ & $6.5 \pm 1.5 \times 10^{6}$ & $6.0 \pm 1.1 \times 10^{6}$ \\
Yeasts (CFU/g) & $7.8 \pm 1.6 \times 10^{7}$ & $8.1 \pm 1.4 \times 10^{7}$ & $8.9 \pm 1.5 \times 10^{7}$ & $9.2 \pm 1.9 \times 10^{7}$ & $9.4 \pm 1.6 \times 10^{7}$ \\
\hline
\end{tabular}

The results obtained (Table 2) showed that LAB and AAB counts decreased (although not significantly, $P>0.05$ ) with the increase in the number of subcultures compared to their corresponding initial counts in the kefir grains. In contrast, the counts of viable yeasts increased (although not significantly, $P>0.05$ ), suggesting that this increase could contribute to the increase in grain weight. Moreover, the counts of LAB and AAB decreased 
slightly at the end of the fourth subculture in parallel with the non-significant $(P>0.05)$ decrease in grain weight. However, it is also possible that the grain microorganisms could produce some extracellular polysaccharide with a chemical structure different from that of kefiran.

Regarding the fermentation yields (Table 3), it can be highlighted that the values of the yield $Y_{X / T S c}$ remained approximately constant in the first three subcultures because biomass production increased in parallel with an increase in the consumption of glucose and fructose. However, the $Y_{X / T S c}$ value decreased in the fourth incubation because the decrease in biomass production was more pronounced than the decrease in the consumption of the two carbon sources (Fig. 1).

Although the yields $Y_{L A / T S C}, Y_{A A / T S C}, Y_{S A / T S C}$ and $Y_{M A / T S C}$ exhibited a decreasing profile (Table 3), the calculated values may not be real, due to the aforementioned hypothesis relating the metabolite production to its possible consumption by some microorganisms present in the kefir grains. However, the values of $Y_{E t / T S c}$ and $Y_{G l y / T S c}$ also showed a decreasing profile until the third subculture, but both yields in the fourth incubation were slightly higher than their corresponding values in the first subculture.

Table 3. Fermentation Yields Calculated at the End of Every Subculture in the Fed-Batch Fermentation A. $Y_{X / T S c}$, $Y_{L A / T S c}, Y_{A A / T S c}, Y_{S A / T S c}, Y_{M A / T S c}, Y_{E t / T S c}$, and $Y_{G l y / T S c}$ are respectively, the Mean Yields (g/g) of Free Biomass (X), Lactic Acid (LA), Acetic Acid (AA), Succinic Acid (SA), Malic Acid (SA), Ethanol (Et) and Glycerol (Gly) on Total Sugars Consumed (TSc).

\begin{tabular}{|c|c|c|c|c|}
\hline \multirow[b]{2}{*}{ Variables } & \multicolumn{4}{|c|}{ Subcultures } \\
\hline & I & II & III & IV \\
\hline$Y_{L A / T S c}$ & 0.045 & 0.008 & 0.002 & 0.002 \\
\hline$Y_{S A / T S c}$ & 0.037 & 0.014 & 0.007 & 0.007 \\
\hline$Y_{M A / T S c}$ & 0.007 & 0.003 & 0.001 & 0.001 \\
\hline$Y_{E t / T S c}$ & 0.191 & 0.177 & 0.171 & 0.195 \\
\hline$Y_{G l y / T S c}$ & 0.080 & 0.071 & 0.070 & 0.086 \\
\hline
\end{tabular}

\subsection{Fed-Batch Fermentation of Red Table Grapes Juice (initial pH 5.99) with Kefir Grains.}

The low initial $\mathrm{pH}$ value of red table grape juice $(3.99 \pm 0.01)$ seemed to influence the kinetics of the different subcultures, probably because of the different optimum $\mathrm{pH}$ values for the growth of each microbial population. According to the results obtained by other researchers, acidic $\mathrm{pH}$ values favored the growth of yeasts. ${ }^{34-35}$ In contrast, the optimum $\mathrm{pH}$ range for higher nutrient assimilation by Streptococcus lactis and S. cremoris strains in a synthetic medium was within 6.00 and 6.50,37 while for Lact. casei CECT 4043 was between 6.50 and 7.00 in whey. ${ }^{38}$ Moreover, for Acetobacter sp. CCTCC M209061, the optimum $\mathrm{pH}$ range for biomass production was between 5.0 and 6.0. ${ }^{39}$

Considering that kefir grain contains different species of Lactococcus, Lactobacillus and Acetobacter, 3,4 it would be logical to select a $\mathrm{pH}$ level between 6.0 and 6.5 to favor the growth of $\mathrm{LAB}$ and $\mathrm{AAB}$. However, the red color of the table grapes juice abruptly turns bright green, when the $\mathrm{pH}$ of changed from 5.99 to 6.00 , which could undoubtedly cause a rejection of the potential probiotic beverage by consumers.

For this reason, a new fermentation (B) was performed (Fig. 2) by using red table grape juice adjusted to 5.99, a more favorable initial $\mathrm{pH}$ level for the growth of LAB and AAB populations, to determine how this fact affects the fermentation kinetics and production of volatile compounds. 
Fermentation B provided increased concentrations $(P<0.05)$ of free biomass, ethanol and glycerol, and higher consumption of total sugars in every fed-batch subculture compared to fermentation A. However, only the yields $Y_{\mathrm{X} / T S \mathrm{~S}}$ and $Y_{\mathrm{Et} / T S \mathrm{~S}}$ in the different subcultures in fermentation B were always higher than in fermentation A (Tables 3 and 4).

Table 4. Fermentation Yields Calculated at the End of Every Subculture in the Fed-Batch Fermentation B.

$Y_{X / T S c}, Y_{L A / T S c}, Y_{A A / T S c}, Y_{S A / T S c}, Y_{M A / T S c}, Y_{E t / T S c}$, and $Y_{G l y / T S c}$ are respectively, the Mean Yields (g/g) of Free Biomass

(X), Lactic Acid (LA), Acetic Acid (AA), Succinic Acid (SA), Malic Acid (SA), Ethanol (Et) and Glycerol (Gly) on Total Sugars Consumed (TSc).

\begin{tabular}{lcccc}
\hline & \multicolumn{3}{c}{ Subcultures } & \\
\hline Variables & I & II & III & IV \\
\hline$Y_{X / T S c}$ & 0.112 & 0.106 & 0.111 & 0.109 \\
\hline$Y_{\text {LA/TSc }}$ & 0.036 & 0.014 & 0.005 & 0.003 \\
\hline$Y_{A A / T S c}$ & 0.056 & 0.039 & 0.041 & 0.042 \\
\hline$Y_{S A / T S c}$ & 0.022 & 0.010 & 0.008 & 0.009 \\
\hline$Y_{M A / T S c}$ & 0.000 & 0.004 & 0.004 & 0.005 \\
\hline$Y_{E t / T S c}$ & 0.194 & 0.205 & 0.221 & 0.211 \\
\hline$Y_{\text {Gly/TSc }}$ & 0.105 & 0.067 & 0.075 & 0.086 \\
\hline
\end{tabular}

As observed in fermentation A, Enterobacteriaciae, and Pseudomonas counts in both the kefir-like beverages were considerably low (Table 1). The counts of rod and coccusshaped $\mathrm{LAB}$, total mesophilic bacteria and $\mathrm{AAB}$ at the end of the four subcultures in fermentation $\mathrm{B}$ were higher $(P<0.05)$ than those obtained in the corresponding subcultures in fermentation A (Table 1). However, the counts of yeasts in the four subcultures in fermentations $\mathrm{A}$ and $\mathrm{B}$ did not show significant differences $(P>0.05)$. Therefore, an initial $\mathrm{pH}$ of 5.99 favored the growth of $\mathrm{LAB}$ and $\mathrm{AAB}$ in comparison to an initial $\mathrm{pH}$ value of 3.99 , but this fact did not significantly affect the viability of yeasts in the red table grape juice.

In the second fed-batch fermentation (Fig. 2), the evolution of $\mathrm{pH}$ conditioned the production of biomass, lactic acid and glycerol, which exhibited greater increases in the first $12 \mathrm{~h}$ of incubation in the different subcultures, when the culture $\mathrm{pH}$ dropped from 5.99 to 4.14 (subculture 1), 4.05 (subculture 2), 4.07 (subculture 3) and 4.12 (subculture 4), just before feeding with fresh grape juice. Although this feeding produced slight increases in the culture $\mathrm{pH}$ (up to $4.24,4.14,4.17$ and 4.22 in subcultures 1, 2, 3 and 4, respectively), little decreases in this variable were observed in the following $12 \mathrm{~h}$ of fermentation in every subculture (Fig. 2). Thus, the final culture $\mathrm{pH}$ values observed in every subculture $(3.90,4.08,4.09$, and 4.12 , respectively) were similar to the initial $\mathrm{pH}$ value of the red table grape juice $(3.99 \pm 0.01)$.

The production rates of ethanol, acetic acid and succinic acid before and after feeding with fresh juice were similar in every subculture, but the production rate of antibacterial activity after feeding was only higher than that before feeding in the second subculture. In contrast, the synthesis rate of malic acid was higher than that after feeding from the second subculture (Fig. 2).

From the comparison of the fed-batch cultures A and B, it could be noted that both the microbial growth and production of ethanol and glycerol did not show the abrupt decrease in the fourth subculture (Fig. 2) observed in the previous fed-batch culture at $\mathrm{pH}$ 3.99 (Fig. 1). This observation suggests that an initial $\mathrm{pH}$ of 5.99 favored the stabilization of the microbial populations of the kefir grain during at least four fed-batch subcultures. In addition, the counts of rod and coccus-shaped LAB and yeasts obtained in the four subcultures were always very near (first and fourth subcultures in fermentation A) or 
greater than $10^{6} \mathrm{CFU} / \mathrm{mL}$. So that, it is previsible that the fermented drinks obtained could produce beneficial effects for consumers. ${ }^{12}$
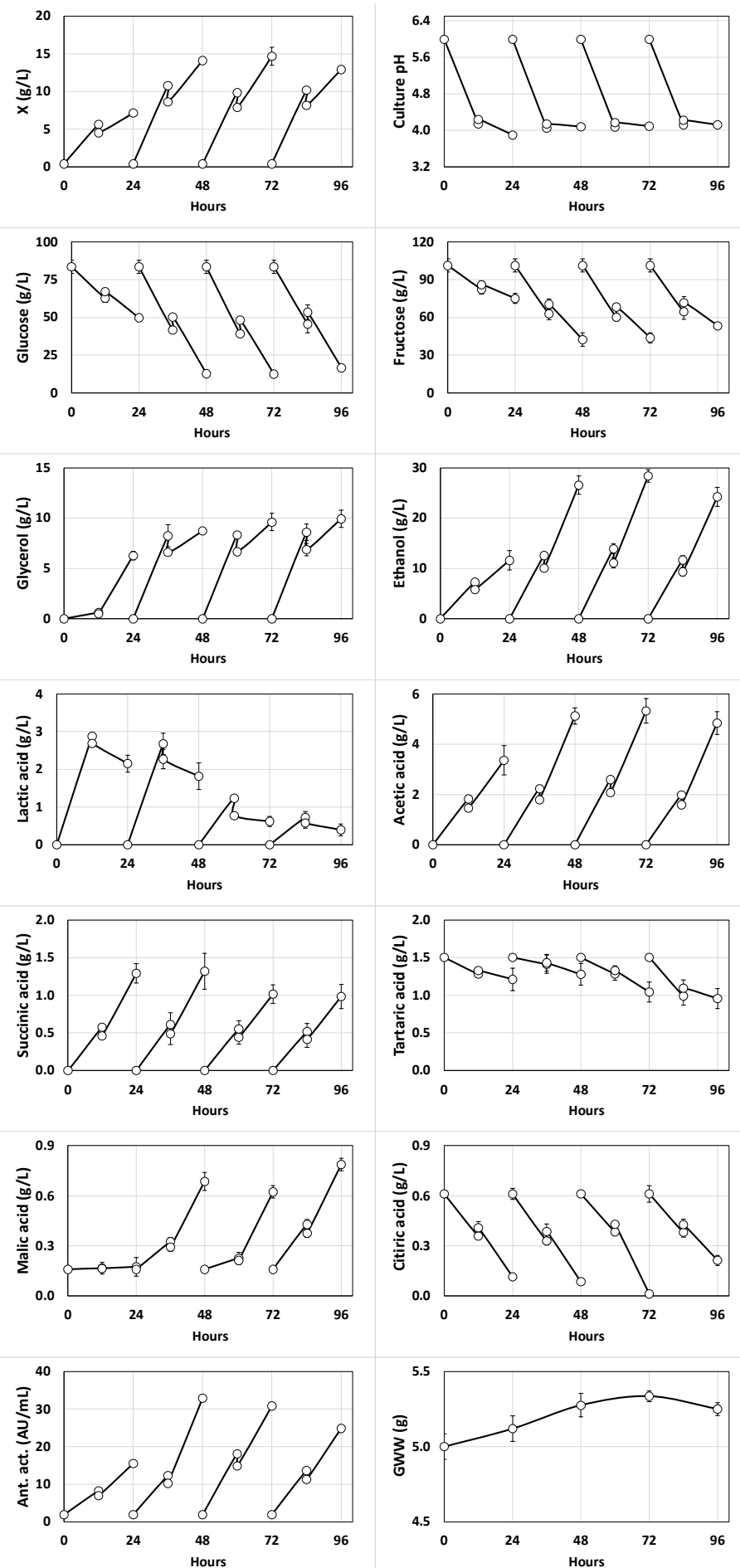

Figure 2. Kinetics of growth $(\mathrm{X})$, culture $\mathrm{pH}$, glucose, fructose, alcohols (glycerol and ethanol), and organic acids (lactic, succinic, tartaric, malic and citric), antibacterial activity (Ant. act.) and grain wet weight (GWW) in the 24-h fed-batch subcultures of red table grapes juice at initial pH 5.99 fermented with kefir grains. The different subcultures were fed with fresh juice at 12, 36, 60 , and $84 \mathrm{~h}$, respectively. 
On the other hand, the growth of kefir grains in fed-batch fermentation B was slightly higher (although not significantly, $P>0.05$ ) compared to the previous fed-batch culture (Figs. 1 and 2).

Another important aspect considered in the production of fermented beverages with fermentative entities containing yeasts, is the production of ethanol. Here, yeasts are important in the production of kefir, due to the production of ethanol and carbon dioxide, which provides a drink with a distinctive flavor and stimulating and effervescent characteristics. $6,9,40$ The mean concentrations of ethanol in all the beverages obtained in the different subcultures of fermentations A and B (Figs. 1 and 2) were higher than the minimum alcoholic strength $(1.2 \%)$ fixed by the European Council ${ }^{41}$ for alcoholic beverages. According to this criterion, all the kefir-like beverages obtained from red table grapes could be considered as alcoholic beverages. However, these beverages contained ethanol concentrations considerably lower than a drink obtained by fermentation of apple with kefir grains $(12.27 \%, \mathrm{v} / \mathrm{v})^{42}$ and some wines produced in Spain ${ }^{42-47}$ (Table 5).

Table 5. Comparison of the Mean Alcoholic Content (\%, v/v) in the Fermented Samples from the Four Subcultures of the Fed-Batch Fermentation A and B with other Fermented Beverages.

\begin{tabular}{|c|c|c|c|c|c|}
\hline & \multicolumn{4}{|c|}{ Subcultures of $24 \mathrm{~h}$} & \multirow[t]{2}{*}{ References } \\
\hline & I & II & III & IV & \\
\hline Fermentation A & 1.3 & 2.7 & 2.6 & 2.3 & This work \\
\hline Fermentation B & 1.5 & 3.4 & 3.6 & 3.1 & This work \\
\hline Apple kéfir & \multicolumn{4}{|c|}{12.27 , after $120 \mathrm{~h}$ of fermentation } & Viana et al. ${ }^{42}$ \\
\hline \multicolumn{6}{|l|}{ Wines } \\
\hline Spanish barrel-aged red wines & \multicolumn{4}{|c|}{$12.0-14.5$} & Garde et al. ${ }^{43}$ \\
\hline Rojal red wine & \multicolumn{4}{|c|}{12.52} & Sánchez et al. ${ }^{44}$ \\
\hline Moravia Dulce red wine & \multicolumn{4}{|c|}{12.70} & \\
\hline Tortosí red wine & \multicolumn{4}{|c|}{12.72} & \\
\hline \multicolumn{5}{|c|}{ White varieties } & Vilanova et al. ${ }^{45}$ \\
\hline Cabernet-sauvignon & \multicolumn{4}{|c|}{11.8} & \\
\hline Pinot noir & \multicolumn{4}{|c|}{13.5} & \\
\hline Tempranillo & \multicolumn{4}{|c|}{11.6} & \\
\hline Merlot & \multicolumn{4}{|c|}{13.1} & \\
\hline \multicolumn{5}{|c|}{ Red varieties } & \\
\hline Chardonnay & \multicolumn{4}{|c|}{14.1} & \\
\hline Pinot blanc & \multicolumn{4}{|c|}{11.6} & \\
\hline Pinot gris & \multicolumn{4}{|c|}{14.6} & \\
\hline Riesling & \multicolumn{4}{|c|}{11.0} & \\
\hline Sauvignon blanc & \multicolumn{4}{|c|}{13.6} & \\
\hline Gewürztraminer & \multicolumn{4}{|c|}{14.3} & \\
\hline Albariño white wine & \multicolumn{4}{|c|}{13.82} & Vilanova and Freire ${ }^{46}$ \\
\hline Loureiro white wine & \multicolumn{4}{|c|}{12.75} & \\
\hline
\end{tabular}

From this observation, it seems reasonable to separate the probiotic cells from the fermented medium to obtain two products with different practical applications. On the one hand, probiotic cells could be separated from the beverage, washed, lyophilized and marketed as an additive for fresh beverages, such as milk or fruit juices. On the other 
hand, the cell-free fermented juice could be marketed as an alcoholic beverage with a low ethanol content (between 1.3 and $3.6 \%, v / v)$ and concentration of sugars $(\sim 10 \mathrm{~g}$ glucose/L and $40 \mathrm{~g}$ fructose/L) considerably lower than those of the red table juice $(80.51 \pm 4.38 \mathrm{~g}$ glucose/L and $99.28 \pm 2.85 \mathrm{~g}$ fructose/L).

\subsection{Volatile Composition of the Different Fermented Samples.}

The concentrations of volatile compounds in a fermented beverage depend on the fermentative entity, the quality and type of fermentation substrate, as well as the fermentation conditions used. ${ }^{47-48}$ So that, the volatile composition of the kefir-like beverages obtained from red table grapes is highly influenced by the complex microbiota of the kefir grains, composed of lactic acid bacteria, acetic acid bacteria and yeasts.

Table 6 shows the concentrations $(\mathrm{mg} / \mathrm{L})$ of volatile products detected in the different fermented beverages obtained from fermentations A and B. As can be seen, 68 volatile compounds were quantified in both the fuit juice and fermented beverages, including 21 alcohols, 13 esters, 6 aldehydes, 7 organic acids, 7 ketones, 3 furans, 2 ethers, 6 hydrocarbons, and 3 volatile compounds included in the other compounds family.

As observed, fed-batch fermentation of red table juices led to an increase in the number and concentration of alcohols, aldehydes (in case of beverages from fermentation B) and organic acids. The concentration of esters also increased, but the number of these volatile compounds increased only in the first subcultures of fermentation A and B (Table 6).

Randazzo et al. ${ }^{12}$ observed an increase in the concentrations of organic acids, alcohols, esters and ketones after batch fermentation of juices from apple, grape, kiwifruit, pomegranate, prickly pear and quince with water kefir microorganisms. In contrast, aldehydes decreased in the fermentations of apple, grape, kiwifruit, pomegranate and quince, ${ }^{12}$ and in the four beverages from fermentation A (Table 6). The latter was probably due to the low $\mathrm{pH}$ values of the juices from apple ( $\mathrm{pH} 3.70)$, grape $(\mathrm{pH} 3.61)$, kiwifruit $(\mathrm{pH}$ 3.06), pomegranate ( $\mathrm{pH} 3.66)$, quince $(\mathrm{pH} 3.19)^{12}$ and red table grapes ( $\left.\mathrm{pH} 3.99\right)$. However, in prickly pear juice ( $\mathrm{pH}$ 6.26), the decrease in aldehydes concentration after fermentation was less pronounced (from 310.56 in the non-fermented juice to $297.32 \mu \mathrm{g} / \mathrm{L}$ in the fermented beverage) than in the above-mentioned fruit juices. These results suggest that the initial $\mathrm{pH}$ could play an important role in the production of aldehydes during fermentation of fruit juices.

Fermentations A and B of red table grapes juice with milk kefir grains decreased the number of ketones, but a significant decrease $(P<0.05)$ in the concentration of ketones was observed only in fermentation B (Table 6). In contrast, ketones content increased after fermentation of grape, kiwifruit, pomegranate, prickly pear and quince with water kefir microorganisms. ${ }^{12}$ However, fermentation of apple juice with the same fermentation entity only produced a slight increase (from 1.57 to $1.94 \mu \mathrm{g} / \mathrm{L}$ ) in the concentration of these volatile compounds. ${ }^{12}$

In the present study, the content and number of furans, ethers, hydrocarbons and other compounds decreased with fermentations, as occurred with ketones (Table 6).

The concentrations of alcohols, aldehydes, organic acids, esters and ketones in the fermented beverages, mainly those with OAV values $>1$ (Table 7), contributed to the increase in the pleasant or unpleasant keynotes of these kefir-like beverages compared to the non-fermented juice.

Thus, the presence of 2-methyl-1-propanol (with OAV always higher than 1.0) and 4-ethyl-2-methoxyphenol (Table 6) could confer unpleasant aromas (solvent, bitter and fusel, or smoky and gammon-like, respectively) to the fermented beverages. However, the presence of 2-methyl-1-propanol at concentrations much higher than $0.55 \mathrm{mg} / \mathrm{L}$ was also detected in four commercialized Galician high-quality orujo spirits:49 Albariño (210 \pm 0.83 mg/L), Mencia ( $265 \pm 1.11 \mathrm{mg} / \mathrm{L})$, Godello (195 \pm 3.02$)$ and Treixadura (302 $\pm 0.78 \mathrm{mg} / \mathrm{L})$.

3-Methyl-1-pentanol with OAV > 1.0 in the kefir-like beverages obtained in the subcultures II, III and IV from fermentations A and B could provide these beverages with pleasant vinous, herbaceous and cacao notes. ${ }^{50}$ 


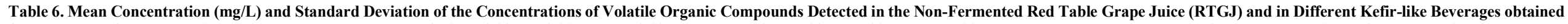

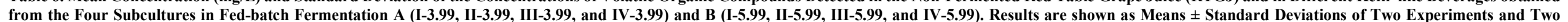
Analytical Replications Each.

\begin{tabular}{|c|c|c|c|c|c|c|c|c|c|c|}
\hline \multirow[b]{2}{*}{ No. } & \multirow[b]{2}{*}{ Compound } & \multirow[b]{2}{*}{ RTGJ } & \multicolumn{4}{|c|}{ Fermentation A } & \multicolumn{4}{|c|}{ Fermentation B } \\
\hline & & & I-3.99 & III-3.99 & III-3.99 & IV-3.99 & I-5.99 & II-5.99 & III-5.99 & IV-5.99 \\
\hline & Alcohols & & & & & & & & & \\
\hline 1 & 1-Propanol & N.d. & N.d. & $1.87 \pm 1.29$ & $1.19 \pm 0.51$ & $1.21 \pm 0.00$ & $0.61 \pm 0.00$ & $2.84 \pm 1.37$ & $1.36 \pm 0.13$ & $1.75 \pm 0.19$ \\
\hline 2 & 2-Methyl-1-propanol & N.d. & $1.65 \pm 0.00$ & $4.29 \pm 0.70$ & $2.88 \pm 0.43$ & $3.16 \pm 0.00$ & $1.93 \pm 0.05$ & $5.95 \pm 0.00$ & $4.71 \pm 0.91$ & $5.84 \pm 0.11$ \\
\hline 3 & 3-Methyl-1-pentanol & N.d. & N.d. & $0.17 \pm 0.01$ & $0.19 \pm 0.06$ & $0.14 \pm 0.00$ & N.d. & $0.23 \pm 0.01$ & $0.13 \pm 0.02$ & $0.13 \pm 0.03$ \\
\hline 4 & 3-Methyl-1-butanol & N.d. & $43.21 \pm 0.00$ & $119.24 \pm 1.03$ & $94.07 \pm 1.77$ & $62.86 \pm 0.00$ & $27.78 \pm 1.54$ & $125.36 \pm 8.62$ & $107.13 \pm 1.34$ & $92.96 \pm 2.09$ \\
\hline 5 & 2-Ethyl-2-hexen-1-ol & N.d. & $0.65 \pm 0.00$ & N.d. & N.d. & N.d. & $0.87 \pm 0.00$ & N.d. & N.d. & N.d. \\
\hline 6 & 2-Phenylethanol & N.d. & $9.41 \pm 0.00$ & $33.33 \pm 1.34$ & $20.34 \pm 3.93$ & $24.96 \pm 0.00$ & $45.90 \pm 0.03$ & $51.46 \pm 10.61$ & $51.16 \pm 7.96$ & $44.12 \pm 3.10$ \\
\hline 7 & 4-Ethyl-2-methoxyphenol & N.d. & N.d. & $0.10 \pm 0.07$ & $0.09 \pm 0.038$ & $0.12 \pm 0.00$ & $0.30 \pm 0.00$ & $0.15 \pm 0.08$ & $0.13 \pm 0.00$ & $0.13 \pm 0.00$ \\
\hline 8 & 3-Methyl-4-heptanol & N.d. & $0.10 \pm 0.00$ & $0.13 \pm 0.04$ & $0.11 \pm 0.06$ & $0.14 \pm 0.00$ & $0.17 \pm 0.04$ & $0.21 \pm 0.02$ & $0.24 \pm 0.16$ & $0.25 \pm 0.01$ \\
\hline 9 & 1-Hexanol & N.d. & $4.03 \pm 0.00$ & $3.47 \pm 0.40$ & $3.26 \pm 0.27$ & $2.99 \pm 0.00$ & $3.23 \pm 0.24$ & $2.59 \pm 0.35$ & $2.91 \pm 0.00$ & $2.63 \pm 0.00$ \\
\hline 10 & 3-Methyl-4-penten-1-ol & N.d. & $0.11 \pm 0.00$ & N.d. & N.d. & N.d. & N.d. & N.d. & N.d. & N.d. \\
\hline 11 & 1-Octin-3-ol & N.d. & $0.04 \pm 0.00$ & N.d. & N.d. & N.d. & N.d. & N.d. & N.d. & N.d. \\
\hline 12 & Cis-3-methylcyclohexanol & N.d. & $0.13 \pm 0.00$ & $0.14 \pm 0.00$ & $0.14 \pm 0.01$ & $0.11 \pm 0.00$ & $0.13 \pm 0.00$ & $0.15 \pm 0.00$ & $0.18 \pm 0.01$ & $0.14 \pm 0.05$ \\
\hline 13 & Trans-2-ethyl-2-hexen-1-ol & N.d. & $0.21 \pm 0.00$ & $0.19 \pm 0.02$ & $0.19 \pm 0.04$ & $0.15 \pm 0.00$ & $0.14 \pm 0.03$ & $0.19 \pm 0.02$ & $0.22 \pm 0.00$ & $0.17 \pm 0.00$ \\
\hline 14 & 4-Cyclohexene-1,2-diol & N.d. & $0.11 \pm 0.00$ & N.d. & N.d. & N.d. & N.d. & N.d. & N.d. & N.d. \\
\hline 15 & 1,3-Butanediol & N.d. & $0.14 \pm 0.00$ & $1.36 \pm 0.13$ & $1.40 \pm 0.81$ & $1.40 \pm 0.00$ & $1.28 \pm 0.00$ & $2.36 \pm 0.24$ & $2.05 \pm 0.50$ & $2.02 \pm 0.35$ \\
\hline 16 & 2-Butyl-1-octanol & N.d. & N.d. & $0.06 \pm 0.09$ & $0.05 \pm 0.08$ & $0.06 \pm 0.00$ & $0.09 \pm 0.00$ & $0.06 \pm 0.00$ & $0.12 \pm 0.00$ & $0.14 \pm 0.00$ \\
\hline 17 & 2-Furanmethanol & $0.372 \pm 0.001$ & N.d. & N.d. & N.d. & N.d. & N.d. & N.d. & N.d. & N.d. \\
\hline 18 & $\begin{array}{l}\text { 2-Cyclohexyl-3-isopropyl- } \\
\text { pent-4-en-2-ol }\end{array}$ & $0.244 \pm 0.020$ & N.d. & N.d. & N.d. & N.d. & N.d. & N.d. & N.d. & N.d. \\
\hline 19 & 1-Hexadecanol & $0.143 \pm 0.011$ & N.d. & N.d. & N.d. & N.d. & N.d. & N.d. & N.d. & N.d. \\
\hline 20 & 2-Hexadecanol & $0.142 \pm 0.007$ & N.d. & N.d. & N.d. & N.d. & N.d. & N.d. & N.d. & N.d. \\
\hline \multirow[t]{3}{*}{21} & (Z)-2-Hexen-1-ol & $0.066 \pm 0.001$ & N.d. & N.d. & N.d. & N.d. & N.d. & N.d. & N.d. & N.d. \\
\hline & $\begin{array}{l}\text { Number of COV } \\
\text { Total concentrations }\end{array}$ & $\begin{array}{c}5 \\
0.967 \pm 0.010^{\mathrm{a}}\end{array}$ & $\begin{array}{c}12 \\
59.81 \pm 9.50^{\mathrm{b}}\end{array}$ & $\begin{array}{c}12 \\
164.37 \pm 26.53^{\mathrm{c}}\end{array}$ & $\begin{array}{c}12 \\
123.91 \pm 20.68^{\mathrm{d}, \mathrm{c}}\end{array}$ & $\begin{array}{c}12 \\
9732+14,40^{\mathrm{e}}\end{array}$ & $\begin{array}{c}12 \\
8243+11.34^{\mathrm{f}}\end{array}$ & $\begin{array}{c}12 \\
19154+28,87^{\mathrm{g}, \mathrm{c}}\end{array}$ & $\begin{array}{c}12 \\
17036+2525^{\mathrm{h}, \mathrm{c}}\end{array}$ & $\begin{array}{c}12 \\
15028+2186^{c}\end{array}$ \\
\hline & Esters & & & & & & & & & \\
\hline 22 & Pentyl acetate & N.d. & $0.62 \pm 0.00$ & $2.56 \pm 0.15$ & $1.62 \pm 0.11$ & $0.30 \pm 0.00$ & $1.27 \pm 0.00$ & $1.79 \pm 0.26$ & $1.71 \pm 0.03$ & $0.87 \pm 0.19$ \\
\hline 23 & Ethyl hexanoate & N.d. & $0.54 \pm 0.00$ & $1.12 \pm 0.40$ & $0.81 \pm 0.14$ & $0.26 \pm 0.00$ & $0.58 \pm 0.00$ & $0.61 \pm 0.17$ & $1.01 \pm 0.07$ & $0.79 \pm 0.01$ \\
\hline 24 & 2-Methylamyl acetate & N.d. & $0.31 \pm 0.00$ & N.d. & N.d. & N.d. & N.d. & N.d. & N.d. & N.d. \\
\hline 25 & 2-Phenylethyl acetate & N.d. & $0.31 \pm 0.00$ & $0.46 \pm 0.14$ & $0.36 \pm 0.19$ & $0.32 \pm 0.00$ & $0.81 \pm 0.26$ & $0.92 \pm 0.32$ & $0.76 \pm 0.07$ & $0.63 \pm 0.06$ \\
\hline 26 & $\begin{array}{l}\text { 3-(Methylthio) } \\
\text { propylnonanoate }\end{array}$ & N.d. & $3.37 \pm 0.00$ & $4.96 \pm 1.97$ & $3.26 \pm 2.13$ & $7.48 \pm 0.01$ & $5.87 \pm 0.92$ & $6.12 \pm 0.96$ & $3.27 \pm 1.30$ & $6.93 \pm 0.21$ \\
\hline 27 & $\begin{array}{l}\text { 2,2-Dimethyl-1-propanol- } \\
\text { acetate }\end{array}$ & N.d. & $0.69 \pm 0.00$ & N.d. & N.d. & N.d. & $1.69 \pm 0.00$ & $1.75 \pm 0.29$ & N.d. & N.d. \\
\hline 28 & $\begin{array}{l}\text { Ethyl octanoate (ethyl } \\
\text { caprylate) }\end{array}$ & N.d. & $0.24 \pm 0.00$ & $0.70 \pm 0.14$ & $0.50 \pm 0.03$ & $0.13 \pm 0.00$ & $0.32 \pm 0.02$ & $0.34 \pm 0.06$ & $0.44 \pm 0.05$ & $0.26 \pm 0.09$ \\
\hline 29 & $\begin{array}{l}\text { 2-Oxo-2-phenylethyl- } \\
\text { (benzoylsulfanyl) acetate }\end{array}$ & $0.27 \pm 0.00$ & N.d. & N.d. & N.d. & N.d. & $0.13 \pm 0.00$ & N.d. & N.d. & N.d. \\
\hline 30 & $\begin{array}{l}\text { 3-Methylene-4-pentenyl } \\
\text { acrylate }\end{array}$ & $0.82 \pm 0.01$ & N.d. & N.d. & N.d. & N.d. & N.d. & N.d. & N.d. & N.d. \\
\hline
\end{tabular}




\begin{tabular}{|c|c|c|c|c|c|c|c|c|c|c|}
\hline 31 & 2-Propenyl formate & $2.23 \pm 0.02$ & N.d. & N.d. & N.d. & N.d. & N.d. & N.d. & N.d. & N.d. \\
\hline 32 & $\begin{array}{l}\text { Heptyl } \\
\text { (methoxycarbonylamino) } \\
\text { propanoate }\end{array}$ & $0.64 \pm 0.00$ & N.d. & N.d. & N.d. & N.d. & N.d. & N.d. & N.d. & N.d. \\
\hline 33 & $\begin{array}{l}\text { 2-O-cyclobutyl 1-O-heptyl } \\
\text { oxalate }\end{array}$ & $0.46 \pm 0.01$ & N.d. & N.d. & N.d. & N.d. & N.d. & N.d. & N.d. & N.d. \\
\hline \multirow[t]{4}{*}{34} & S-heptyl propanethioate & $0.64 \pm 0.01$ & N.d. & N.d. & N.d. & N.d. & N.d. & N.d. & N.d. & N.d. \\
\hline & Number of COV & 6 & 7 & 5 & 5 & 5 & 7 & 6 & 5 & 5 \\
\hline & Total concentrations & $5.07 \pm 0.63^{\mathrm{a}}$ & $6.09 \pm 0.91^{\mathrm{b}, \mathrm{a}}$ & $9.79 \pm 1.46^{\mathrm{c}}$ & $6.56 \pm 0.96^{\mathrm{d}, \mathrm{a}, \mathrm{b}}$ & $8.50 \pm 2.05^{\mathrm{e}, \mathrm{a}, \mathrm{a}, \mathrm{c}, \mathrm{d}}$ & $10.67 \pm 1.61^{\mathrm{f}, \mathrm{c}, \mathrm{e}}$ & $11.54 \pm 1.70^{\mathrm{g}, \mathrm{c}, \mathrm{f}}$ & $7.19 \pm 0.98^{\mathrm{h}, \mathrm{b}, \mathrm{c}, \mathrm{d}, \mathrm{e}}$ & $9.48 \pm 1.89^{\text {c,de,f,g,h }}$ \\
\hline & Aldehydes & & & & & & & & & \\
\hline 35 & 2-Ethyl hexanal & N.d. & N.d. & $0.18 \pm 0.06$ & $0.15 \pm 0.07$ & $0.20 \pm 0.00$ & $0.18 \pm 0.13$ & $0.30 \pm 0.05$ & $0.40 \pm 0.21$ & $0.39 \pm 0.03$ \\
\hline 36 & 3-(Methylthio)-nonanal & N.d. & $0.064 \pm 0.001$ & N.d. & N.d. & N.d. & N.d. & N.d. & $\begin{array}{l}\text { N.d. } \\
\text { N }\end{array}$ & N.d. \\
\hline 37 & (E)-2-nonenal & N.d. & $0.09 \pm 0.00$ & $0.19 \pm 0.06$ & $0.18 \pm 0.03$ & $0.13 \pm 0.01$ & $0.08 \pm 0.00$ & $0.12 \pm 0.02$ & $0.15 \pm 0.01$ & $0.14 \pm 0.03$ \\
\hline 38 & 2,2-Dimethyl propanal & N.d. & N.d. & $0.01 \pm 0.00$ & $0.02 \pm 0.00$ & N.d. & $0.17 \pm 0.00$ & $0.22 \pm 0.00$ & $0.22 \pm 0.00$ & $0.16 \pm 0.00$ \\
\hline 39 & (E)-2-Hexenal & $0.29 \pm 0.00$ & N.d. & N.d. & N.d. & N.d. & N.d. & N.d. & N.d. & N.d. \\
\hline \multirow[t]{4}{*}{40} & $\begin{array}{l}\text { 5-Methyl-2- } \\
\text { furancarboxaldehyde }\end{array}$ & $0.09 \pm 0.00$ & N.d. & N.d. & N.d. & N.d. & N.d. & N.d. & N.d. & N.d. \\
\hline & Number of COV & 2 & 2 & 3 & 3 & 2 & 3 & 3 & 3 & 3 \\
\hline & Total concentrations & $0.39 \pm 0.12 \mathrm{a}$ & $0.15 \pm 0.04 \mathrm{~b}$ & $0.37 \pm 0.09^{\mathrm{c}, \mathrm{a}}$ & $0.35 \pm 0.08^{\mathrm{d}, \mathrm{a}, \mathrm{c}}$ & $0.33 \pm 0.09^{e, a, b, c, d}$ & $0.43 \pm 0.09^{\mathrm{f,a,c,d,e}}$ & $0.65 \pm 0.13^{\mathrm{g}, \mathrm{c}, \mathrm{f}}$ & $0.76 \pm 0.16^{\mathrm{h}, \mathrm{g}}$ & $0.69 \pm 0.15^{\mathrm{g}, \mathrm{h}}$ \\
\hline & Organic acids & & & & & & & & & \\
\hline 41 & Hexanoic acid (caproic) & N.d. & $0.85 \pm 0.00$ & $1.16 \pm 0.69$ & $1.45 \pm 1.21$ & $2.59 \pm 0.01$ & $4.49 \pm 1.76$ & $3.36 \pm 2.82$ & $2.01 \pm 0.21$ & $1.76 \pm 0.56$ \\
\hline 42 & Octanoic acid (caprylic) & N.d. & $0.56 \pm 0.00$ & $1.22 \pm 0.99$ & $1.83 \pm 1.63$ & $1.68 \pm 0.01$ & $4.83 \pm 0.01$ & $3.41 \pm 3.28$ & $2.04 \pm 0.12$ & $2.35 \pm 1.10$ \\
\hline 43 & Nonanoic acid (pelargonic) & N.d. & N.d. & $0.09 \pm 0.06$ & $0.11 \pm 0.08$ & $0.07 \pm 0.00$ & $0.16 \pm 0.00$ & $0.20 \pm 0.11$ & $0.24 \pm 0.12$ & $0.25 \pm 0.02$ \\
\hline 44 & Acetic acid & $0.70 \pm 0.03$ & $1.05 \pm 0.00$ & $1.04 \pm 0.36$ & $1.62 \pm 0.53$ & $3.90 \pm 0.47$ & $0.95 \pm 0.24$ & $0.87 \pm 0.03$ & $1.53 \pm 0.11$ & $2.08 \pm 0.43$ \\
\hline 45 & Pentanoic acid & N.d. & $0.08 \pm 0.00$ & $0.22 \pm 0.17$ & $0.25 \pm 0.22$ & $0.31 \pm 0.00$ & $0.20 \pm 0.11$ & $0.43 \pm 0.25$ & $0.43 \pm 0.36$ & $0.37 \pm 0.21$ \\
\hline 46 & 4-Methyl pentanoic acid & $0.11 \pm 0.00$ & N.d. & N.d. & N.d. & N.d. & N.d. & N.d. & N.d. & N.d. \\
\hline \multirow[t]{4}{*}{47} & 2-Methyl-hexanoic acid & N.d. & $0.16 \pm 0.00$ & $0.34 \pm 0.06$ & $0.21 \pm 0.05$ & $0.16 \pm 0.00$ & $0.60 \pm 0.00$ & $0.62 \pm 0.10$ & $0.63 \pm 0.36$ & $0.52 \pm 0.25$ \\
\hline & Number of COV & 2 & 5 & 6 & 6 & 6 & 6 & 6 & 6 & 6 \\
\hline & Total concentrations & $0.82 \pm 0.26^{\mathrm{a}}$ & $2.69 \pm 0.43^{\mathrm{b}}$ & $4.06 \pm 0.53^{\mathrm{c}}$ & $5.47 \pm 0.81^{\mathrm{d}, \mathrm{c}}$ & $8.72 \pm 1.53^{\mathrm{e}}$ & $11.23 \pm 2.11^{\mathrm{f}}$ & $8.89 \pm 1.47^{\mathrm{g}, \mathrm{e}}$ & $6.89 \pm 0.86^{\mathrm{h}, \mathrm{d}, \mathrm{e}, \mathrm{g}}$ & $7.33 \pm 0.98^{\mathrm{d}, \mathrm{e}, \mathrm{g}, \mathrm{h}}$ \\
\hline & Ketones & & & & & & & & & \\
\hline 48 & 3,3-Dimethyl-2-butanone & $0.04 \pm 0.00$ & N.d. & N.d. & N.d. & N.d. & N.d. & N.d. & N.d. & N.d. \\
\hline 49 & 4-Methyl-2-hexanone & $0.05 \pm 0.00$ & $0.05 \pm 0.00$ & $0.05 \pm 0.00$ & $0.05 \pm 0.00$ & $0.05 \pm 0.00$ & $0.04 \pm 0.00$ & $0.04 \pm 0.00$ & $0.06 \pm 0.00$ & $0.05 \pm 0.00$ \\
\hline 50 & 3-Hexanone & $0.16 \pm 0.00$ & $0.16 \pm 0.00$ & $0.14 \pm 0.00$ & $0.16 \pm 0.00$ & $0.16 \pm 0.00$ & $0.12 \pm 0.00$ & $0.14 \pm 0.00$ & $0.12 \pm 0.00$ & $0.11 \pm 0.00$ \\
\hline 51 & 2,6-Dimethyl-4-heptanone & $0.27 \pm 0.00$ & $0.66 \pm 0.00$ & $0.67 \pm 0.00$ & $0.71 \pm 0.00$ & $0.77 \pm 0.01$ & $0.47 \pm 0.00$ & $0.56 \pm 0.00$ & $0.39 \pm 0.00$ & $0.52 \pm 0.00$ \\
\hline 52 & 5-Dodecanone & $0.09 \pm 0.00$ & N.d. & N.d. & N.d. & N.d. & N.d. & N.d. & N.d. & N.d. \\
\hline 53 & Dihydroxyacetone & $0.35 \pm 0.00$ & N.d. & N.d. & N.d. & N.d. & N.d. & N.d. & N.d. & N.d. \\
\hline \multirow[t]{4}{*}{54} & 1-Acetyloxy-2-propanone & $0.13 \pm 0.00$ & N.d. & N.d. & N.d. & N.d. & N.d. & N.d. & N.d. & N.d. \\
\hline & Number of COV & 7 & 3 & 3 & 3 & 3 & 3 & 3 & 3 & 3 \\
\hline & Total concentrations & $1.09 \pm 0.12^{\mathrm{a}}$ & $0.87 \pm 0.24^{\mathrm{b}, \mathrm{a}}$ & $0.86 \pm 0.25^{\mathrm{c}, \mathrm{a}, \mathrm{b}}$ & $0.93 \pm 0.26^{\mathrm{d}, \mathrm{ab}, \mathrm{b}, \mathrm{c}}$ & $0.98 \pm 0.28^{\text {e,a,b,c,d }}$ & $0.63 \pm 0.17^{\mathrm{f}, \mathrm{b}}$ & $0.75 \pm 0.21^{\mathrm{g}, \mathrm{b}, \mathrm{c}, \mathrm{d}, \mathrm{f}}$ & $0.57 \pm 0.14^{\mathrm{h}, \mathrm{b}, \mathrm{f}, \mathrm{g}}$ & $0.68 \pm 0.19^{\mathrm{b}, \mathrm{d}, \mathrm{fg}, \mathrm{h}}$ \\
\hline & Furans & & & & & & & & & \\
\hline 55 & $\begin{array}{l}\text { 3-Butyldihydro-2(3H)- } \\
\text { furanone }\end{array}$ & $0.10 \pm 0.00$ & N.d. & N.d. & N.d. & N.d. & N.d. & N.d. & N.d. & N.d. \\
\hline 56 & 5-Methyl-2(3H)-furanone & $0.96 \pm 0.02$ & N.d. & N.d. & N.d. & N.d. & N.d. & N.d. & N.d. & N.d. \\
\hline \multirow[t]{3}{*}{57} & Tetrahydro-2,5-dimethyl-furan & $0.10 \pm 0.00$ & $0.20 \pm 0.00$ & $0.18 \pm 0.00$ & $0.22 \pm 0.00$ & $0.38 \pm 0.00$ & $0.72 \pm 0.00$ & $0.49 \pm 0.00$ & $0.43 \pm 0.00$ & $0.64 \pm 0.00$ \\
\hline & Number of COV & 3 & 1 & 1 & 1 & 1 & 1 & 1 & 1 & 1 \\
\hline & Total concentrations & $1.16 \pm 0.01^{\mathrm{a}}$ & $0.20 \pm 0.12^{\mathrm{b}}$ & $0.18 \pm 0.11^{\mathrm{c}, \mathrm{b}}$ & $0.22 \pm 0.12^{\mathrm{d}, \mathrm{b}, \mathrm{c}}$ & $0.38 \pm 0.22^{e, b, c, d}$ & $0.72 \pm 0.42^{\text {f,a,b,d,e }}$ & $0.49 \pm 0.28^{\mathrm{g}, \mathrm{b}, \mathrm{c}, \mathrm{e}, \mathrm{f}}$ & $0.43 \pm 0.25^{\mathrm{h}, \mathrm{b}, \mathrm{d}, \mathrm{e}, \mathrm{g}}$ & $0.64 \pm 0.37^{\mathrm{a}, \mathrm{b}, \mathrm{d}, \mathrm{e}, \mathrm{fg}}$ \\
\hline
\end{tabular}




\begin{tabular}{|c|c|c|c|c|c|c|c|c|c|c|}
\hline & Ethers & & & & & & & & & \\
\hline 58 & 1-Butoxy-3-methyl-2-butene & $0.14 \pm 0.00$ & N.d. & N.d. & N.d. & N.d. & N.d. & N.d. & N.d. & N.d. \\
\hline \multirow[t]{4}{*}{59} & Ethyl-1-propenyl ether & $0.19 \pm 0.00$ & N.d. & N.d. & N.d. & N.d. & N.d. & N.d. & N.d. & N.d. \\
\hline & Number of COV & 2 & N.d. & N.d. & N.d. & N.d. & N.d. & N.d. & N.d. & N.d. \\
\hline & Total concentrations & $0.33 \pm 0.04$ & N.d. & N.d. & N.d. & N.d. & N.d. & N.d. & N.d. & N.d. \\
\hline & Hydrocarbons & & & & & & & & & \\
\hline 60 & 2,4-Dimethyl-2-pentene & $0.06 \pm 0.00$ & N.d. & N.d. & N.d. & N.d. & N.d. & N.d. & N.d. & N.d. \\
\hline 61 & (Z)-3-Dodecene & $0.26 \pm 0.00$ & $0.26 \pm 0.00$ & $0.24 \pm 0.00$ & $0.23 \pm 0.00$ & $0.29 \pm 0.00$ & $0.23 \pm 0.00$ & $0.22 \pm 0.00$ & $0.29 \pm 0.00$ & $0.29 \pm 0.00$ \\
\hline 62 & 4-Cyclopenten-1,3-dione & $0.45 \pm 0.01$ & N.d. & N.d. & N.d. & N.d. & N.d. & N.d. & N.d. & N.d. \\
\hline 63 & 1,2,3-Trimethyl-benzene & $0.42 \pm 0.01$ & $0.35 \pm 0.00$ & $0.33 \pm 0.00$ & $0.35 \pm 0.00$ & $0.36 \pm 0.00$ & $0.41 \pm 0.00$ & $0.44 \pm 0.00$ & $0.45 \pm 0.00$ & $0.53 \pm 0.00$ \\
\hline 64 & Butylhydroxytoluene & $1.43 \pm 0.02$ & $1.53 \pm 0.02$ & $1.45 \pm 0.01$ & $1.63 \pm 0.02$ & $1.78 \pm 0.01$ & $1.16 \pm 0.02$ & $1.61 \pm 0.02$ & $1.83 \pm 0.03$ & $1.95 \pm 0.02$ \\
\hline \multirow[t]{4}{*}{65} & Trichloromethane & $0.27 \pm 0.01$ & N.d. & N.d. & N.d. & N.d. & $0.32 \pm 0.00$ & N.d. & N.d. & $0.32 \pm 0.01$ \\
\hline & Number of COV & 6 & 3 & 3 & 3 & 3 & 4 & 3 & 3 & 4 \\
\hline & Total concentrations & $2.90 \pm 0.48^{\mathrm{a}}$ & $2.14 \pm 0.59^{\mathrm{b}}$ & $2.02 \pm 0.56^{\mathrm{c}, \mathrm{a}, \mathrm{b}}$ & $2.22 \pm 0.64^{\mathrm{d}, \mathrm{a}, \mathrm{b}, \mathrm{c}}$ & $2.43 \pm 0.69^{\mathrm{e}, \mathrm{a}, \mathrm{b}, \mathrm{c}, \mathrm{d}}$ & $2.13 \pm 0.43^{\mathrm{f}, \mathrm{a}, \mathrm{b}, \mathrm{c}, \mathrm{d}, \mathrm{e}}$ & $2.27 \pm 0.63^{\mathrm{a}, \mathrm{b}, \mathrm{c}, \mathrm{d}, \mathrm{f}}$ & $2.57 \pm 0.71^{\mathrm{a}, \mathrm{b}, \mathrm{c}, \mathrm{d}, \mathrm{f}}$ & $3.09 \pm 0.73^{\mathrm{a}, \mathrm{b}, \mathrm{c}}$ \\
\hline & Other compounds & & & & & & & & & \\
\hline 66 & 3-Trifluoroacetoxy dodecane & $0.08 \pm 0.00$ & N.d. & $0.04 \pm 0.00$ & N.d. & N.d. & N.d. & N.d. & N.d. & N.d. \\
\hline 67 & 1-Hydroperoxyhexane & $0.14 \pm 0.00$ & N.d. & N.d. & N.d. & N.d. & N.d. & N.d. & N.d. & N.d. \\
\hline \multirow[t]{3}{*}{68} & Cis-2-methyl-3-propyl-oxirane & $0.34 \pm 0.01$ & N.d. & N.d. & N.d. & N.d. & $0.09 \pm 0.00$ & N.d. & N.d. & $0.06 \pm 0.00$ \\
\hline & Number of COV & 3 & 0 & 1 & 0 & 0 & 1 & 0 & 0 & 1 \\
\hline & Total concentrations & $0.57 \pm 0.14^{\mathrm{a}}$ & $0^{\mathrm{b}}$ & $0.04 \pm 0.02^{\mathrm{c}}$ & $0^{\mathrm{b}}$ & $0^{\mathrm{b}}$ & $0.09 \pm 0.05^{\mathrm{c}}$ & $0^{\mathrm{b}}$ & $0^{\mathrm{b}}$ & $0.06 \pm 0.03^{\mathrm{c}}$ \\
\hline
\end{tabular}

N.d.: not detected. - Mean values within rows followed by the same letter are not significantly different by Ryan-Gabriel-Welsch Multiple F-test $(\mathrm{P}=0.05)$ after a significant ANOVA (P $<0.05)$. 
The aroma of the kefir-like beverages could be negatively affected when the concen- 1 tration of 3-methyl-1-butanol surpassed its odor detection threshold, since this amyl alco- 2 hol is related to alcohol, malt, burned, harsh, nail polish notes. ${ }^{51}$ Considering that low 3 concentrations of isoamyl alcohols are related to alcoholic beverages with a light body, ${ }^{49} \quad 4$ it can be assumed that the red table grape beverages from subcultures II, III and IV in 5 fermentations $\mathrm{A}$ and $\mathrm{B}$ have a better body than those to the corresponding first subcultures (Table 6).

Additionally, the ratios of isoamyl alcohol/2-methyl-1-propanol (between 14.4 and 32.7) and 2-methyl-1-propanol/1-propanol (between 2.1 and 3.5) in the different red table grape beverages were higher than 1.0, suggesting that these products could have good organoleptic characteristics according to this criterion. ${ }^{47}$

2-Phenylethanol, detected at concentrations between 9.41 and $51.46 \mathrm{mg} / \mathrm{L}$, could contribute to the pleasant aroma of red table grape beverages, introducing sweetish and floral nuances in them. ${ }^{47}$ This compound was detected at lower concentrations in kefir-like beverages produced from carrot: $54.34 \mu \mathrm{g} / \mathrm{L}$, fennel: $54.34 \mu \mathrm{g} / \mathrm{L}$, melon: $393.97 \mu \mathrm{g} / \mathrm{L}$, strawberry: $215.72 \mu \mathrm{g} / \mathrm{L}$ and tomato: $255.27 \mu \mathrm{g} / \mathrm{L}^{11}$ or apple: $117.29 \mu \mathrm{g} / \mathrm{L}$, grape: $588.26 \mu \mathrm{g} / \mathrm{L}$, kiwifruit: $2241.74 \mu \mathrm{g} / \mathrm{L}$, pomegranate: $1002.72 \mu \mathrm{g} / \mathrm{L}$, prickly pear: $514.19 \mu \mathrm{g} / \mathrm{L}$ and quince: $1438.45 \mu \mathrm{g} / \mathrm{L} .{ }^{12}$

The presence of 1-hexanol, with an aromatic description of "coconut-like", "harsh" and "pungent", in alcoholic beverages could have a positive impact on the aroma at concentrations $\leq 20 \mathrm{mg} / \mathrm{L}$, but at high levels, this volatile compound can negatively affect the aroma of these beverages. ${ }^{47}$ Then, the presence of this compound did not negatively affect the aroma of the red table grape beverages, since the concentration of 1-hexanol in them was always lower than $20 \mathrm{mg} / \mathrm{L}$ (Table 6). Similarly, the kefir-like beverages obtained by fermentation of juices from vegetables ${ }^{11}$ and Mediterranean fruits ${ }^{12}$ with water kefir microorganisms had 1-hexanol concentrations lower than $20 \mathrm{mg} / \mathrm{L}$.

Four esters with OAV > 1.0 (pentyl acetate, ethyl hexanoate, 2-phenylethyl acetate and ethyl octanoate), related to fruity/floral/green aromas ${ }^{11}$, were detected in the eight kefir-like beverages (Tables 6 and 7). Similarly, the concentrations of ethyl hexanoate, 2phenylethyl acetate and ethyl octanoate increased with the fermentation of carrot, fennel, melon, strawberry and tomato ${ }^{11}$ or apple, grape, kiwifruit, pomegranate, prickly pear and quince ${ }^{12}$ with water kefir grains. Production of these compounds during fermentation, related to the metabolic activity of yeast strains present in the kefir grains, contributes to the pleasant aroma (rose and honey) of the beverages. ${ }^{12}$

Two aldehydes (2-ethyl hexanal and (E)-2-nonenal) were detected in the fermented samples although only the (E)-2-nonenal exhibited a considerably higher OAV in all subcultures, due to its low threshold value (190 ng/L) (Tables 6 and 7). The latter compound is responsible for important off-flavors ("sawdust" or "plank") in beverages, 52 producing a fatty, tallow, beans, cucumber and woody-like aroma. ${ }^{53}$

Organic acids can play an important role in the aroma of alcoholic beverages contributing to their final sensory quality. ${ }^{54}$ In the kefir-like red table grapes beverages, all organic acids were detected at concentrations lower than their corresponding odor threshold (Table 7), suggesting that the contributions of these volatile compounds to the final aroma of the beverages could be very low. A similar trend was observed in wines obtained from Brazilian exotic tropical fruits (cacao, cupuassu, gabiroba, jaboticaba and umbu) and Portuguese grape (Tinta Negra Mole variety). ${ }^{55}$

2-Methyl-2-hexanone, 3-hexanone, and 2,6-dimethyl-4-heptanone were detected in the kefir-like beverages at concentrations higher than their corresponding ODT values (Table 7). Therefore, the three ketones can also contribute to the aroma of beverages with fruity or ethereal (in case of 3- hexanone) notes.

However, the contribution of each independent odorant compound to the aroma of an alcoholic beverage can also be influenced by the contribution of other volatile compounds detected, producing a typical aroma of the beverage. ${ }^{56}$ 
Table 7. Odor Activity Value (OAV) and Odor Detection Threshold (ODT) of the Volatile Organic Compounds Detected in the Non-Fermented Red Table Grape Juice (RTGJ) and in Different Kefir-like Beverages obtained from the Four Subcultures in Fed-batch Fermentation A (I-3.99, II-3.99, III-3.99, and IV-3.99) and B (I-5.99, II-5.99, III-5.99, and IV-5.99).

\begin{tabular}{|c|c|c|c|c|c|c|c|c|c|c|c|c|}
\hline & & & & \multicolumn{9}{|c|}{ OVA } \\
\hline No. & Compound & ODT (mg/L) & Descriptor & RTGJ & I-3.99 & II-3.99 & III-3.99 & IV-3.99 & I-5.99 & II-5.99 & III-5.99 & IV-5.99 \\
\hline 1 & 1-Propanol & $9^{57}$ & ripe fruit, alcoholl ${ }^{61}$ & & & 0.21 & 0.13 & 0.14 & 0.07 & 0.32 & 0.15 & 0.20 \\
\hline 2 & 2-Methyl-1-propanol & $0.55^{57}$ & $\begin{array}{l}\text { alcohol, banana, medicinal, } \\
\text { solvent, nail polish }{ }^{47}\end{array}$ & & 3.01 & 7.81 & 5.23 & 5.75 & 3.51 & 10.82 & 8.56 & 10.61 \\
\hline 3 & 3-Methyl-1-pentanol & $0.0075^{57}$ & vinous, herbaceous, cacao $^{50}$ & & & 2.33 & 2.49 & 1.84 & & 3.03 & 1.71 & 1.76 \\
\hline 4 & 3-Methyl-1-butanol & $50-70^{57}$ & $\begin{array}{l}\text { whiskey, malt, burned, harsh, } \\
\text { nail polish }{ }^{51}\end{array}$ & & $0.72 *$ & $1.99^{*}$ & $1.57^{*}$ & $1.05^{*}$ & $0.46^{*}$ & $2.09^{*}$ & $1.79 *$ & $1.55^{*}$ \\
\hline 5 & 2-Ethyl-2-hexen-1-ol & $\mathrm{Nf}$ & citrus, floral, sweet ${ }^{62}$ & & & & & & & & & \\
\hline 6 & 2-Phenylethanol & $0.5642^{57}$ & $\begin{array}{l}\text { rose, sweetish, } \\
\text { perfumed }^{47}\end{array}$ & & 16.67 & 59.07 & 36.05 & 44.24 & 81.34 & 91.21 & 90.68 & 78.19 \\
\hline 7 & 4-Ethyl-2-methoxyphenol & $0.08925^{57}$ & smoky, gammon-like ${ }^{63}$ & & & 1.17 & 0.99 & 1.36 & 3.36 & 1.68 & 1.48 & 1.46 \\
\hline 8 & 3-Methyl-4-heptanol & $0.078-0.420^{57}$ & $\mathrm{Nf}$ & & $0.41 *$ & $0.52 *$ & $0.43^{*}$ & $0.58^{*}$ & $0.69^{*}$ & $0.84 *$ & $0.96^{*}$ & $1.00^{*}$ \\
\hline 9 & 1-Hexanol & $0.0056^{57}$ & coconut, harsh, pungent ${ }^{47}$ & & 71.96 & 61.96 & 58.25 & 53.46 & 57.70 & 46.18 & 52.00 & 46.93 \\
\hline 10 & 3-Methyl-4-penten-1-ol & $\mathrm{Nf}$ & $\mathrm{Nf}$ & & & & & & & & & \\
\hline 11 & 1-Octin-3-ol & $\mathrm{Nf}$ & $\mathrm{Nf}$ & & & & & & & & & \\
\hline 12 & Cis-3-methylcyclohexanol & $\mathrm{Nf}$ & $\mathrm{Nf}$ & & & & & & & & & \\
\hline 13 & Trans-2-ethyl-2-hexen-1-ol & $\mathrm{Nf}$ & $\mathrm{Nf}$ & & & & & & & & & \\
\hline 14 & 4-Cyclohexene-1,2-diol & $\mathrm{Nf}$ & $\mathrm{Nf}$ & & & & & & & & & \\
\hline 15 & 1,3-Butanediol & $10-20^{57}$ & Woody ${ }^{64}$ & & $0.01 *$ & $0.09^{*}$ & $0.09 *$ & $0.09^{*}$ & $0.08^{*}$ & $0.16^{*}$ & $0.14 *$ & $0.13^{*}$ \\
\hline 16 & 2-Butyl-1-octanol & $\mathrm{Nf}$ & $\mathrm{Nf}$ & & & & & & & & & \\
\hline 17 & 2-Furanmethanol & $4.5^{57}$ & burned sugar $^{62}$ & 0.08 & & & & & & & & \\
\hline 18 & $\begin{array}{l}\text { 2-Cyclohexyl-3-isopropyl- } \\
\text { pent-4-en-2-ol }\end{array}$ & $\mathrm{Nf}$ & $\mathrm{Nf}$ & & & & & & & & & \\
\hline 19 & 1-Hexadecanol & $0.75^{58}$ & floral, waxy $y^{65}$ & 0.19 & & & & & & & & \\
\hline 20 & 2-Hexadecanol & $\mathrm{Nf}$ & $\mathrm{Nf}$ & & & & & & & & & \\
\hline 21 & (Z)-2-Hexen-1-ol & $0.3593^{57}$ & green grass, herb ${ }^{66}$ & 0.184 & & & & & & & & \\
\hline 22 & Pentyl acetate & $0.043^{57}$ & Fruity ${ }^{67}$ & & 14.46 & 59.60 & 37.67 & 7.02 & 29.49 & 41.70 & 39.84 & 20.19 \\
\hline 23 & Ethyl hexanoate & $0.005^{57}$ & fruity $^{68}$ & & 108.00 & 223.20 & 162.80 & 52.20 & 115.60 & 122.20 & 201.80 & 157.20 \\
\hline 24 & 2-Methylamyl acetate & $\mathrm{Nf}$ & $\mathrm{Nf}$ & & & & & & & & & \\
\hline 25 & 2-Phenylethyl acetate & $0.25^{57}$ & rose, honey ${ }^{69}$ & & 1.24 & 1.83 & 1.44 & 1.30 & 3.25 & 3.69 & 3.02 & 2.54 \\
\hline 26 & $\begin{array}{l}\text { 3-(Methylthio) } \\
\text { propylnonanoate }\end{array}$ & $\mathrm{Nf}$ & $\mathrm{Nf}$ & & & & & & & & & \\
\hline 27 & $\begin{array}{l}\text { 2,2-Dimethyl-1-propanol- } \\
\text { acetate }\end{array}$ & $\mathrm{Nf}$ & $\mathrm{Nf}$ & & & & & & & & & \\
\hline 28 & $\begin{array}{l}\text { Ethyl octanoate (ethyl } \\
\text { caprylate) }\end{array}$ & $0.0193^{57}$ & fruity, floral ${ }^{69}$ & & 12.54 & 36.17 & 26.11 & 6.94 & 16.74 & 17.67 & 22.90 & 13.42 \\
\hline 29 & $\begin{array}{l}\text { 2-Oxo-2-phenylethyl- } \\
\text { (benzoylsulfanyl)acetate }\end{array}$ & $\mathrm{Nf}$ & $\mathrm{Nf}$ & & & & & & & & & \\
\hline 30 & $\begin{array}{l}\text { 3-Methylene-4-pentenyl } \\
\text { acrylate }\end{array}$ & $\mathrm{Nf}$ & $\mathrm{Nf}$ & & & & & & & & & \\
\hline 31 & 2-Propenyl formate & $\mathrm{Nf}$ & $\mathrm{Nf}$ & & & & & & & & & \\
\hline
\end{tabular}




\begin{tabular}{|c|c|c|c|c|c|c|c|c|c|c|c|c|}
\hline 32 & $\begin{array}{l}\text { Heptyl } \\
\text { (methoxycarbonylamino) } \\
\text { propanoate }\end{array}$ & $\mathrm{Nf}$ & $\mathrm{Nf}$ & & & & & & & & & \\
\hline 33 & $\begin{array}{l}\text { 2-O-cyclobutyl 1-O-heptyl } \\
\text { oxalate }\end{array}$ & $\mathrm{Nf}$ & $\mathrm{Nf}$ & & & & & & & & & \\
\hline 34 & S-heptyl propanethioate & $\mathrm{Nf}$ & $\mathrm{Nf}$ & & & & & & & & & \\
\hline 35 & 2-Ethyl hexanal & $41^{59}$ & Beany $^{59}$ & & & 0.004 & 0.004 & 0.005 & 0.004 & 0.007 & 0.010 & 0.009 \\
\hline 36 & 3-(Methylthio)-nonanal & $\mathrm{Nf}$ & $\mathrm{Nf}$ & & & & & & & & & \\
\hline 37 & (E)-2-nonenal & $0.00019^{57}$ & fatty, tallow, beans, cucumber, woody-like ${ }^{53}$ & & 457.89 & 984.21 & 926.32 & 710.53 & 436.84 & 652.63 & 778.95 & 736.84 \\
\hline 38 & 2,2-Dimethyl propanal & $\mathrm{Nf}$ & $\mathrm{Nf}$ & & & & & & & & & \\
\hline 39 & (E)-2-Hexenal & $0.11^{57}$ & fresh, fruity, green-like, sweet ${ }^{53}$ & 2.67 & & & & & & & & \\
\hline 40 & $\begin{array}{l}\text { 5-Methyl-2- } \\
\text { furancarboxaldehyde }\end{array}$ & $\mathrm{Nf}$ & $\mathrm{Nf}$ & & & & & & & & & \\
\hline 41 & Hexanoic acid (caproic) & $3.0^{57}$ & sweet, cheesy ${ }^{53}$ & & 0.28 & 0.39 & 0.48 & 0.86 & 1.49 & 1.12 & 0.67 & 0.59 \\
\hline 42 & Octanoic acid (caprylic) & $8.8^{57}$ & sweet, cheesy ${ }^{53}$ & & 0.06 & 0.14 & 0.21 & 0.19 & 0.55 & 0.39 & 0.23 & 0.27 \\
\hline 43 & Nonanoic acid (pelargonic) & $4.6-9.0^{57}$ & fatty-like $\mathrm{s}^{53}$ & & & $0.01 *$ & $0.02 *$ & $0.01 *$ & $0.02 *$ & $0.03 *$ & $0.04 *$ & $0.04 *$ \\
\hline 44 & Acetic acid & $99^{57}$ & vinegar, peppers, green, fruity, floral, sour ${ }^{70}$ & 0.01 & 0.01 & 0.01 & 0.02 & 0.04 & 0.01 & 0.01 & 0.02 & 0.02 \\
\hline 45 & Pentanoic acid & $11^{57}$ & sweaty, fruity ${ }^{63}$ & & 0.01 & 0.02 & 0.02 & 0.03 & 0.02 & 0.04 & 0.04 & 0.03 \\
\hline 46 & 4-Methylpentanoic acid & $0.81^{57}$ & sweaty $^{71}$ & 0.14 & & & & & & & & \\
\hline 47 & 2-Methylhexanoic acid & $0.92-2.70^{23}$ & sweat, oily ${ }^{72}$ & & $0.09 *$ & $0.19 *$ & $0.12 *$ & $0.09 *$ & $0.33 *$ & $0.34 *$ & $0.35^{*}$ & $0.29 *$ \\
\hline 48 & 3,3-Dimethyl-2-butanone & $\mathrm{Nf}$ & $\mathrm{Nf}$ & & & & & & & & & \\
\hline 49 & 4-Methyl-2-hexanone & $0.00081-0.0041^{57}$ & fruity $^{73}$ & $19.55^{*}$ & $19.15^{*}$ & $19.55^{*}$ & $20.37 *$ & $19.55^{*}$ & $17.11 *$ & $17.92 *$ & $22.81 *$ & $19.55^{*}$ \\
\hline 50 & 3-Hexanone & $0.041-0.081^{57}$ & ethereal, grape ${ }^{74}$ & $2.57^{*}$ & $2.66^{*}$ & $2.33^{*}$ & $2.71 *$ & $2.67 *$ & $1.90^{*}$ & $2.34 *$ & $2.00 *$ & $1.88^{*}$ \\
\hline 51 & 2,6-Dimethyl-4-heptanone & $0.11^{60}$ & fruity, sweet ${ }^{75}$ & 2.50 & 6.04 & 6.11 & 6.49 & 6.99 & 4.29 & 5.12 & 3.54 & 4.69 \\
\hline 52 & 5-Dodecanone & $\mathrm{Nf}$ & $\mathrm{Nf}$ & & & & & & & & & \\
\hline 53 & Dyhidroyiacetone & $\mathrm{Nf}$ & $\mathrm{Nf}$ & & & & & & & & & \\
\hline 54 & 1-Acetyloxy-2-propanone & $\mathrm{Nf}$ & $\mathrm{Nf}$ & & & & & & & & & \\
\hline 55 & $\begin{array}{l}\text { 3-Butyldihydro-2(3H)- } \\
\text { furanone }\end{array}$ & $\mathrm{Nf}$ & $\mathrm{Nf}$ & & & & & & & & & \\
\hline 56 & 5-Methyl-2(3H)-furanone & $\mathrm{Nf}$ & $\mathrm{Nf}$ & & & & & & & & & \\
\hline 57 & $\begin{array}{l}\text { Tetrahydro-2,5-dimethyl- } \\
\text { furan }\end{array}$ & $\mathrm{Nf}$ & $\mathrm{Nf}$ & & & & & & & & & \\
\hline 58 & 1-Butoxy-3-methyl-2-butene & $\mathrm{Nf}$ & $\mathrm{Nf}$ & & & & & & & & & \\
\hline 59 & Ethyl-1-propenyl ether & $\mathrm{Nf}$ & $\mathrm{Nf}$ & & & & & & & & & \\
\hline 60 & 2,4-Dimethyl-2-pentene & $\mathrm{Nf}$ & $\mathrm{Nf}$ & & & & & & & & & \\
\hline 61 & (Z)-3-Dodecene & $\mathrm{Nf}$ & $\mathrm{Nf}$ & & & & & & & & & \\
\hline 62 & 4-Cyclopenten-1,3-dione & $\mathrm{Nf}$ & $\mathrm{Nf}$ & & & & & & & & & \\
\hline 63 & 1,2,3-Trimethyl-benzene & $\mathrm{Nf}$ & $\mathrm{Nf}$ & & & & & & & & & \\
\hline 64 & Butylhydroxytoluene & $\mathrm{Nf}$ & $\mathrm{Nf}$ & & & & & & & & & \\
\hline 65 & Trichloromethane & $0.12^{57}$ & pleasant, etheric, nonirritating ${ }^{76}$ & 2.29 & & & & & 2.69 & & & 2.65 \\
\hline 66 & 3-Trifluoroacetoxy dodecane & $\mathrm{Nf}$ & $\mathrm{Nf}$ & & & & & & & & & \\
\hline 67 & 1-Hydroperoxyhexane & $\mathrm{Nf}$ & $\mathrm{Nf}$ & & & & & & & & & \\
\hline 68 & $\begin{array}{l}\text { Cis-2-methyl-3-propyl- } \\
\text { oxirane }\end{array}$ & $\mathrm{Nf}$ & $\mathrm{Nf}$ & & & & & & & & & \\
\hline
\end{tabular}




\subsection{Statistical Analysis of the Microbiological, Chemical and Volatile Compositions of the} Fermented Samples.

Principal component analysis (PCA) was conducted to interpret the relationship between the microbiological, chemical and volatile compositions of the different fermented samples and identify the main components that best discriminate between the samples analyzed. ${ }^{12,51}$ In the analysis of the microbiological, chemical and volatile compositions of the different kefir-like beverages from res tables juice, the Bartlett's sphericity test (significance $=0.000<0.050$ ) indicated that the PCA can be applied to the data. ${ }^{12}$

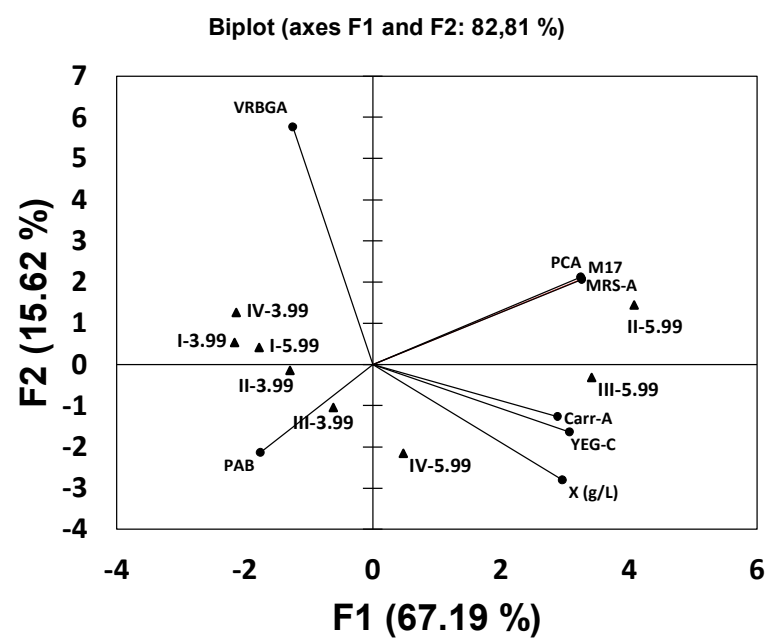

Figure 3. Principal component analysis (PCA) store plot based on the differences between the microbial counts in the fermented red table grape beverages obtained from fed-batch fermentations A (I-3.99, II-3.99, I-3.99, and IV-3.99) and B (I-5.99, II-5.99, I-5.99, and IV-5.99).

The PCA analysis of the microbial loads in the different fermented samples with respect to the red table grape juice showed that the two first factors (F1 and F2 representing 67.19 and $15.62 \%$ of the total variability of the data, respectively) had eigenvalues higher than 1 , and both explained $82.81 \%$ of the total variance (Fig. 3). According to this biplot graph, Factor 1 was positively correlated with the counts of meshopilic bacteria (in PCA agar) and coccus LAB (in M17 agar), rod LAB (in MRS-A agar), AAB (in Carr-A agar) and yeasts (in YEG-C agar) and with the concentrations of free cells $(X)$ in the beverages. Thus, according to Factor 1, the beverages obtained in subcultures II-, III- and IV-5.99 (fermentation B) were separated from beverages I-, II-, III- and IV-3.99 (fermentation A) and I-5.99 (fermentation B). This was because beverages II-, III- and IV-5.99 (fermentation B) had higher counts in meshopilic bacteria, coccus and rod LAB, AAB, and yeast agar and concentrations of free cells $(X)$ compared to beverages I-, II-, III-, IV-3.99 and I-5.99. These differences could be related to the above-mentioned differences between both the $\mathrm{pH}$ value and nutrient composition of the table grape juice (in fermentations A and B) in comparison to the pasteurized whole milk UHT used for activation of the kefir grains.

Factor 2 provided a lesser contribution to separate the kefir-like beverages since according to this factor, the samples were closely located along the x-axis (Fig. 3).

PCA based on the chemical composition of the different beverages (Fig. 4) clearly shows the differences between the non-fermented juice and the kefir-like beverages obtained from fermentations A and B. In this case, Factors 1 and 2 accounting for 64.48 and $25.69 \%$ of total variance, respectively. Both factors explained $90.17 \%$ of the total variance. The first factor was positively correlated with alcohols (ethanol and glycerol) and acetic acid content and negatively correlated with sugar (glucose and fructose) concentration. According to Factor 1, samples (the non-fermented juice and kefir-like beverages I-3.99 
and I-5.99) with the highest glucose and fructose concentrations and lowest alcohols and acetic acid levels were clearly separated from the other fermented samples. Factor 2 separated the samples according to their high lactic and succinic acid concentration and low final $\mathrm{pH}$ values.

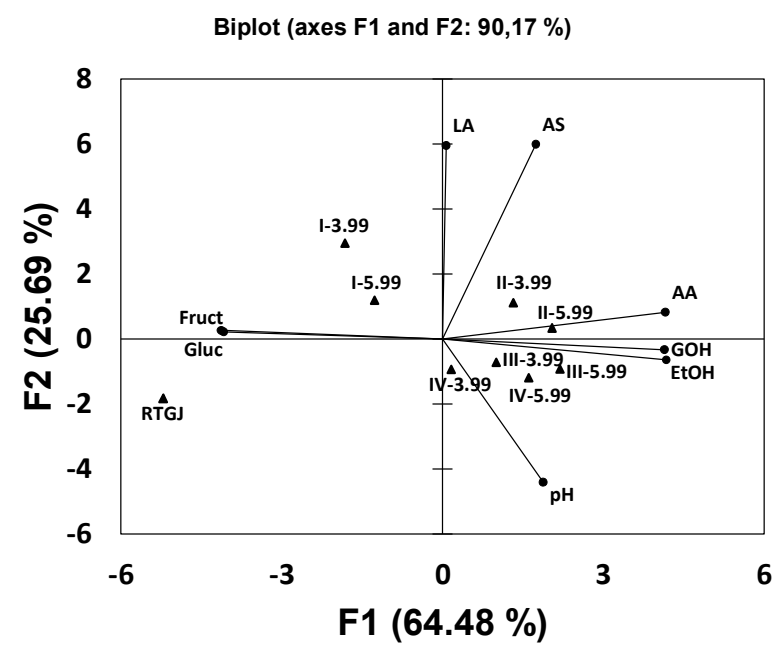

Figure 4. PCA analysis based on the final $\mathrm{pH}$ values and the concentrations of glucose (Gluc), fructose (Fruct), alcohols (EtOH: ethanol and GOH: glycerol) and organic acids (LA: lactic acid, AA: acetic acid, AS: succinic acid) in the non-fermented red table grape juice (RGTJ) and fermented samples obtained from fed-batch fermentations A (I-3.99, II-3.99, I-3.99, and IV-3.99) and B (I-5.99, II-5.99, I-5.99, and IV-5.99).

In any case, the fermented beverages III-3.99, III-5.99, and IV-5.99 were grouped in the lower-right quarter, indicating that their chemical composition was similar. The beverage IV-3.99 was also located in this quarter, but further away from the group formed by the other three fermented beverages. The same occurred with the samples II-3.99 and II5.99, grouped in the higher-right quarter and, I-3.99 and I-5.99 grouped in the higher-left quarter. This indicates that the chemical composition of the fermented beverages was different from that of the non-fermented juice (Fig. 4).



Figure 5. PCA analysis of volatile compound families (Table 6) in the non-fermented red table grape juice (RGTJ) and fermented samples obtained from fed-batch fermentations A (I-3.99, II3.99, I-3.99, and IV-3.99) and B (I-5.99, II-5.99, I-5.99, and IV-5.99). 
Regarding the volatile composition, PCA was conducted (Fig. 5) by considering the total concentration of the main different compound families (alcohols, esters, aldehydes, organic acids, ketones, furans, ethers, hydrocarbons and other compounds) present in the non-fermented red table grape juice and beverages obtained from the subcultures I, II, III, and IV in the fed-batch fermentation A and B (Table 6). In this case, two factors with eigenvalues $>1.00$ (accounting for 53.22 and $26.15 \%$ of total variance, respectively) were obtained, explaining $79.38 \%$ of the total variance.

Considering the biplot shown in Figure 5, it can be observed that again, the nonfermented juice was the most different sample, being located on the higher-right quarter as an independent sample due to the higher contents in ethers, other compounds, furans and ketones (Table 6). The four fermented samples corresponding to fermentation B (initial $\mathrm{pH}$ 5.99) were grouped togheter on the higher-left quarter in correspondence with their higher contents in alcohols, esters, aldehydes and organic acids, compared to the non-fermented RTGJ and kefir-like beverages from fermentation A. Finally, the four fermented samples corresponding to fermentation A (initial pH 3.99) were grouped on the lower-right (sample I-3.99) and lower-left (samples II-, III- and IV-3.99) quarters in correspondence with their higher contents in ketones compared to the corresponding samples from fermentation B (Table 6). This indicates that the initial $\mathrm{pH}$ of red grape table juice undoubtedly influenced the aromatic characteristics of the beverages obtained (Fig. 5).

The sample I-3.99 was the most different fermented red grape table juice (Fig. 5) probably due to the different initial $\mathrm{pH}$ (3.99) and media composition between the red table juice and the activation medium (UHT whole milk, pHi =6.75), as indicated before. In the subsequent subcultures (II, III and IV-3.99), the concentrations of volatile compounds increased, suggesting that the microorganisms of the kefir grain were more adapted to the acidic $\mathrm{pH}$ of the red grape table juice.

In contrast, higher concentrations of volatile compounds were obtained in the four subcultures of fermentation B, compared to the corresponding subcultures in fermentation A. This observation suggests that in the first subculture (0-24 h) of fermentation B, the microorganisms of the kefir grains adapted better to the red grape table juice, since the initial $\mathrm{pH}$ level (5.99) of this substrate was closer to that of the UHT whole milk.

These results obtained in the PCA analysis (Figs. 3, 4 and 5) are in good agreement with the results obtained in the fermentation kinetics of red grape table juices in fermentations $\mathrm{A}$ and B (Figs. 1 and 2).

\section{Materials and Methods}

\subsection{Kefir Grains, Activation and Conservation.}

The milk kefir grains CIDCA AGK1 used in this study were obtained from the Center for Research and Development in Food Cryotechnology (CIDCA, La Plata, Argentina). Before being used as a fermentation entity to produce the kefir-like beverages, the grains were activated with two transfers in a pasteurized ultra-high temperature (UHT) whole milk (Central Lechera Asturiana, Asturias, Spain), with the following composition (g/L), as declared by the producer: $\mathrm{pH}, 6.75$; carbohydrates, 46.0; proteins, 32.0; fats, 36.0; saturated fats, 24.0; salt, 1.0 and calcium, 1.2.

For activation 77 , the kefir grains were separated from the coverage liquid (milk) by filtration through a plastic strainer, weighed (approximately $30.6 \mathrm{~g}$, wet weight) and added to a $1 \mathrm{~L}$ Pyrex bottle containing $1 \mathrm{~L}$ pasteurized whole milk UHT. Subsequently, the bottle was covered with a cheesecloth and it was secured with a rubber band and incubated at room temperature away from direct sunlight, at room temperature at 150 rpm for $24 \mathrm{~h}$. Then, the kefir grains were separated from the fermented milk under sterile conditions by filtration through a plastic strainer, washed with sterile distilled water and after the second activation in milk, the grains were used as the inoculum for the production of the kefir-like beverages.

The grains were kept at 4 and $-20^{\circ} \mathrm{C}$ in pasteurized whole milk UHT for storage at short and long times. 


\subsection{Juice Preparation and Fermentation Conditions.}

Juice extracted from red table grapes (Red Globe, category I, Peru), obtained from a Shopping Center (Gadis) in Ourense (Spain), was used as the fermentation substrate. To obtain the juice, the grapes were separated from the clusters and washed three times with sterile distilled water to minimize the presence of traces of possible pesticides used for conservation of the fruit.

Subsequently, the grapes were broken and then squeezed by pressing them in a plastic strainer with the aid of a spatula, to obtain a juice free of skins and seeds. The yield obtained was approximately $366 \mathrm{~mL}$ juice per $\mathrm{kg}$ of fruit used.

Duplicate fed-batch fermentations were conducted at room temperature and $150 \mathrm{rpm}$ for $24 \mathrm{~h}$, with four transfers of the kefir grains in fresh juice, using $250 \mathrm{~mL}$ culture bottles containing 100-mL juice at an initial pH of 3.99 (fermentation A) or 5.99 (fermentation B). In the first 24-h cultures, the juices at $\mathrm{pH}$ values of 3.99 (duplicate $250 \mathrm{~mL}$ culture bottles A1) or 5.99 (duplicate $250 \mathrm{~mL}$ culture bottles B1) were inoculated with $5 \mathrm{~g}$ of the previously activated kefir grains. After $12 \mathrm{~h}$ of incubation, the flasks were removed from the incubator and aliquots of $20 \mathrm{~mL}$ of fermented juice of each flask were aseptically taken to determine the concentrations of free biomass, sugars and fermentation products. Then, $20 \mathrm{~mL}$ of fresh red table grape juice were added to each flask, and after recording the $\mathrm{pH}$, the flasks were incubated again under the same conditions up to $24 \mathrm{~h}$, when the fermentation was stopped (first subculture).

The fermented media were filtered through a sterile plastic strainer to separate the grains, which were washed with sterile distilled water, air-dryed for $10 \mathrm{~min}$ in tissue paper in a biosafety cabinet and weighed before their use as inoculum in the corresponding next 24-h culture (duplicate culture bottles A2 and B2). The second (24 - $48 \mathrm{~h}$ ), third (48 $72 \mathrm{~h}$ ) and fourth $(72-96 \mathrm{~h})$ fed-batch subcultures were carried out under the same conditions as the first subculture.

After separation of the kefir grains, the fermented media obtained at the end of each subculture $(24,48,72$, and $96 \mathrm{~h}$ ) were divided into three aliquots. The first aliquot $(10 \mathrm{~mL})$ was used to quantify the colony forming units (CFU) of bacteria (rod and mesophilic LAB, total mesophilic, Enterobacteriaceae, Pseudomonas, and AAB) and yeasts.

The second aliquot $(80 \mathrm{~mL})$ was centrifuged $\left(5000 \mathrm{rpm} / 5 \mathrm{~min}\right.$ at $\left.4{ }^{\circ} \mathrm{C}\right)$ and the pellets obtained were used to measure the concentration of free biomass in the kefir-like beverages. The resulting supernatant was divided into two subaliquots. The first subaliquot (10 $\mathrm{mL}$ ) was used to measure the culture $\mathrm{pH}$ and the concentrations of sugars and fermentation products (ethanol, glycerol, lactic acid and acetic acid). The second subaliquot $(70 \mathrm{~mL})$ was used to measure the concentrations of volatile compounds.

The second aliquot $(10 \mathrm{~mL})$ was acidified to $\mathrm{pH} 3.5$ with $5 \mathrm{~N} \mathrm{HCl}$, heated for $3 \mathrm{~min}$, centrifuged (5000 rpm/15 min at $4{ }^{\circ} \mathrm{C}$ ) and. The cell-free supernatant obtained was adjusted to $\mathrm{pH} 6.0$ and used to determine the antibacterial activity of the beverages. ${ }^{19}$

\subsection{Microbiological Counts in the Fermentation Medium.}

Serial decimal dilutions of samples from the first aliquot were made and plated in triplicate on MRS (de Man, Rogosa and Sharpe) agar (pH 5.4), M17 agar, PCA (plate count agar), double-layered VRBGA (violet red bile glucose agar), PAB (Pseudomonas agar base) containing $10 \mathrm{~g} / \mathrm{L}$ cetrimide fucidin, Carr agar, and YEG (yeast extract-glucose) agar for enumeration of rod lactic acid bacteria (LAB), mesophilic LAB, total mesophilic (TM), Enterobacteriaceae, Pseudomonas, ${ }^{12}$ acetic acid bacteria $(\mathrm{AAB})^{78}$ and yeasts, respectively.

Amphotericin B, at a final concentration of $0.1 \mathrm{~g} / \mathrm{L}$, was added to the MRS (MRS-A) and Carr (Carr-A) agar media after media sterilization to prevent fungal growth, and chloramphenicol, at a final concentration of $0.1 \mathrm{~g} / \mathrm{L}$, was added to YEG (YEG-C) agar medium after media sterilization to prevent bacterial growth. The plates were incubated anaerobically at $30^{\circ} \mathrm{C}$ for $48 \mathrm{~h}$ (MRS-A and M17), or aerobically at $30^{\circ} \mathrm{C}$ for $72 \mathrm{~h}$ (PCA), $37^{\circ} \mathrm{C}$ for $24 \mathrm{~h}$ (VRBGA), $20{ }^{\circ} \mathrm{C}$ for $48 \mathrm{~h}(\mathrm{PAB}), 30^{\circ} \mathrm{C}$ for $48 \mathrm{~h}$ (Carr-A) and $25^{\circ} \mathrm{C}$ for $48 \mathrm{~h}$ (YEG-C). 
Results (means \pm standard deviations of three experiments and two analytical replications each) were expressed as log CFU (colony forming units) per $\mathrm{mL}$ fermented juice.

\subsection{Analytical Methods.}

The pellets obtained after centrifuging the second aliquot were washed in saline $(0.8 \%(\mathrm{w} / \mathrm{v}) \mathrm{NaCl})$ and centrifuged $\left(5000 \mathrm{rpm} / 5 \mathrm{~min}\right.$ at $\left.4{ }^{\circ} \mathrm{C}\right)$ two times and after re-suspending the washed cells again in saline, the optical density (OD) of each sample was measured at $700 \mathrm{~nm}$. The OD values were converted to cell dry weight (CDW) from a standard curve (CDW vs OD) to quantify the free biomass released from the kefir grains into the culture medium. ${ }^{19,77}$

Concentrations of glucose, fructose, ethanol, glycerol, lactic acid and acetic acid were quantified by a high-performance liquid chromatography (HPLC) system equipped with an ION-300 Organic Acids column (length $300 \mathrm{~mm}$, internal diameter $7.8 \mathrm{~mm}$ ) with a precolumn IONGUARD ${ }^{\mathrm{TM}}$ (polymeric guard column), both obtained from Tecknokroma $\mathrm{S}$. Coop. C. Ltda, Barcelona, Spain. Sugars and fermentation products were separated at 60 $-65{ }^{\circ} \mathrm{C}$ using a $0.012 \mathrm{~N}$ sulfuric acid aqueous mobile phase flowing at $0.4 \mathrm{~mL} / \mathrm{min}$ and detected using a refractometer with a refractive index detector. Solutions of glucose, fructose, ethanol, glycerol, lactic acid and acetic acid at concentration between 0.1 and 10.0 $\mathrm{g} / \mathrm{L}$ were used as standards. Before HPLC analysis, all samples and standards were filtered using a syringe filter $(0.22-\mu \mathrm{m}$ pore size, $25-\mathrm{mm}$ diameter disk filters, Membrane Solutions, Dallas, TX, USA). ${ }^{20}$ All analytical determinations were performed in triplicate.

\subsection{Antibacterial Activity Quantification.}

The antibacterial activity against C. piscicola CECT 4020 (indicator strain) was quantified using a photometric bioassay and expressed as activity units (AU) per milliliter cellfree supernatant, as described in Costas et al. ${ }^{19}$

\subsection{Chemical Standards and Reagents.}

Sodium sulphate anhydrous (99\%) was purchased from Merck (Darmstadt, Germany). Ethanol, diethyl ether and hexane, of analytical grade, were purchased from Merck (Darmstadt, Germany). All chemical standards used for identification and the internal standard (4-methyl-2-pentanol) were supplied by Aldrich (Aldrich Chemical, Switzerland).

\subsection{Volatile compounds analysis.}

A liquid-liquid extraction method was applied for the isolation of volatile compounds. One milliliter of an internal standard solution (1.058 $\mathrm{g}$ of 4-methyl-2-pentanol per L of ethanol) was added to a 5-mL sample. Each sample was extracted with $2 \mathrm{~mL}$ of diethyl ether-hexane (1:1, v/v) stirred at $300 \mathrm{rpm}$ for $1 \mathrm{~min}$. After $5 \mathrm{~min}$ at cold temperature, the organic extract was dehydrated using anhydrous sodium sulphate. Then, $2 \mu \mathrm{L}$ of the organic extract was injected into the chromatograph in splitter mode (30 s).

\subsection{Chromatographic analyses.}

The separation, identification and quantification of volatile compounds were performed on a GC 7820 A gas chromatograph (Agilent Technologies, Santa Clara, CA, USA) coupled with a 5975 Series MSD, Agilent mass spectrometer detector. The GC-MS system was equipped with an ZB-Wax column (Phenomenex; $60 \mathrm{~m} \times 0.25 \mathrm{~mm} \times 0.25 \mu \mathrm{m}$ film thickness). The temperature of the column began at $45^{\circ} \mathrm{C}$ and was held for 2 min, increased $2{ }^{\circ} \mathrm{C} / \mathrm{min}$ to $225^{\circ} \mathrm{C}$. The constant column flow was $1.2 \mathrm{~mL} / \mathrm{min}$, using hydrogen as the carrier gas, and the injection port was at $250{ }^{\circ} \mathrm{C}$. The mass spectra were scanned at $70 \mathrm{eV}$ over a mass range from $\mathrm{m} / \mathrm{z} 10$ to 1000 .

\subsection{Identification and Quantification.}


All volatile compounds were identified using mass spectra, retention indices (RI), and retention time (RT), (authentic chemicals and Willey spectral library collection). In some cases, pure reference compounds were used to confirm the results. Identification was considered tentative when based entirely on mass spectral data.

The quantification procedure was conducted using the internal standard quantification method, using 4-methyl-2-pentanol as an internal standard. The relative peak areas were calculated in relation to the peak area of the internal standard. Volatile compound determinations were performed in duplicate for each fermented beverage.

\subsection{Determination of odor activity values.}

The odor activity values (OAV) were calculated as the ratio between the concentration of a volatile compound in the beverage and its corresponding odor detection threshold (ODT, mg/L). ${ }^{78}$ Volatile compound with an $\mathrm{OAV} \geq 1$ was considered to have a direct impact on aroma of beverages..$^{78}$ The ODT values used in the present study were determined in water. ${ }^{57-60}$

\subsection{Enumeration of Microorganisms on the Kefir Grains.}

To determine the microbial counts in the kefir grains before and after each subculture, four different duplicate cultures were carried out. In the first culture, $1 \mathrm{~g}$ of kefir grains was inoculated into $20 \mathrm{~mL}$ of red table juice (initial $\mathrm{pH}$ of 3.99 or 5.99) and incubated for $24 \mathrm{~h}$ in the same conditions as those used in the production experiments. The second, third and fourth duplicated cultures were composed of two, three and four 24-h fed-batch subcultures, respectively.

After separation of the fermented media by filtration at the end of each culture (24, 48,72 , and $96 \mathrm{~h}$ in the first, second, third and fourth culture, respectively), the grains were dried as indicated above. Subsequently, a $0.5 \mathrm{~g}$ sample of kefir grains was introduced into a stomacher plastic bag, and subsequently, $50 \mathrm{~mL}$ saline $(0.8 \%(\mathrm{w} / \mathrm{v}) \mathrm{NaCl})$ were added. The content was shredded for $15 \mathrm{~min}$ at high speed in a Stomacher (Masticator, IUL Instruments, Barcelona, Spain). Then, two $0.5 \mathrm{~mL}$ aliquots of the resulting kefir grain suspension were used to prepare appropriate decimal dilutions in sterile saline solution. These decimal dilutions diluted were plated in triplicate on MRS-A, Carr-A, and YEG-C agar media for enumeration of $\mathrm{LAB}, \mathrm{AAB}$, and yeasts, respectively. Results were expressed as $\log \mathrm{CFU}$ (colony forming units) per $\mathrm{g}$ of wet kefir grains.

\subsection{Statistical analyses.}

The mean concentrations of the fermentation variables (culture $\mathrm{pH}$, free biomass, microbial counts, glucose, fructose, ethanol, glycerol, lactic acid and acetic acid) and volatile compounds of the different fermented juices were statistically compared using the oneway independent analysis of variance (ANOVA) with the Tukey (in case of equal variances) or Games-Howell (in case of unequal variances) post hoc tests, after analyzing the homogeneity of the variances with the Levene's test.

All comparisons were made using the software package IBM SPSS Statistics for Windows (Version 21.0, IBM SPSS Inc., Armonk, NY, 2012) with a level of significance of $5 \%$.

Principal component analysis (PCA) module of the same software package was used to study the relationship among the non-fermented and fermented samples according to their chemical, microbiological, and volatile composition, after using Barlett's sphericity test to determine the suitability of the data for PCA analysis. ${ }^{12}$ The factors with eigenvalues $>1.0$, according to the Kaiser criterion, were selected for the PCA.

Author Contributions: For research articles with several authors, a short paragraph specifying their individual contributions must be provided. The following statements should be used "Conceptualization, JMD, NPG, SC; methodology, DLB, RGR, SC; software, JCM, NPG; validation, JMD, NPG, SC; formal analysis, DLB, RGR, NPG; investigation, DLB, RGR, SC; resources, DLB, RGR, SC; data curation, JMD, NPG; writing-original draft preparation, DLB, RGR, SC; writing-review and 
editing, JMD, NPG, JCM; visualization, NPG; supervision, NPG; project administration, NPG; funding acquisition, JMD, NPG, JCM. All authors have read and agreed to the published version of the manuscript." Please turn to the CRediT taxonomy for the term explanation. Authorship must be limited to those who have contributed substantially to the work reported.

Funding: This work was supported by the Cluster de Investigación y Transferencia Agroalimentaria del Campus del Auga (CITACA), University of Vigo, Spain. Founded by Xunta de Galicia, Grant number ED431E 2018/07.

Institutional Review Board Statement: Not applicable.

Informed Consent Statement: Not applicable.

Acknowledgments: Delicia L. Bazán thanks to the National University of Jaén (Perú) and the National Fellowship Program (PRONABEC) for their research grant (President of the Republic 2017I"- PRONABEC - Perú). Pablo G. del Río thanks to the Ministry of Science, Innovation, and Universities of Spain for his FPU research grant (FPU16/04077).

Conflicts of Interest: The authors declare no conflict of interest

\section{References}

1. Cais-Sokolińska, D.; Wójtowski, J.; Pikul, J. Rheological, texture and sensory properties of kefir from mare's milk and its mixtures with goat and sheep milk. Mljekarstvo/Dairy 2016, 66, 272-281.

2. Farnworth, E.R.; Mainville, I. Kefir-A fermented milk product. In Handbook of fermented functional foods, edition no. 2; Farnworth, E.R., Ed.; CRC Press, Taylor \& Francis Group LLC: Boca Raton, Florida, USA, 2008; pp.103-110.

3. Abraham, A.; De Antoni, G. Characteristics of kefir grain grown in milk and in soy milk. J. Dairy Res. 1999, 66, 327-333.

4. Piermaria, J.A.; de la Canal, M.L.; Abraham, A.G. Gelling properties of kefiran, a food-grade polysaccharide obtained from kefir grain. Food Hydrocoll. 2008, 22, 1520-1527.

5. Gösta, M.; López, A. Manual de industrias Lácteas. Tetra Pak AB Processing Systems, Mundi-Prensa Libros, Madrid, España, 2003.

6. Fiorda, F.A.; Pereira, G.V.M.; Thomaz-Soccol, V.; Medeiros, A.P.; Rakshit, S.K.; Soccol, C.R. Development of kefir-based probiotic beverages with DNA protection and antioxidant activities using soybean hydrolyzed extract, colostrum and honey. LWT - Food Sci. Technol. 2016, 68, 690-697.

7. Hertzler, S.R.; Clancy, S.M. Kefir improves lactose digestion and tolerance in adults with lactose maldigestion. J. Am. Diet. Assoc. 2003, 103, 582-587.

8. Liu, J.R.; Wang, S.Y.; Chen, M.J.; Chen, H.L.; Yueh, P.Y.; Lin, C.W. Hypocholesterolaemic effects of milk-kefir and soyamilkkefir in cholesterol-fed hamsters. Br. J. Nut. 2006, 95, 939-946.

9. Ismaiel, A.A.; Ghaly, M.F.; El-Naggar, A.K. Some physicochemical analyses of kefir produced under different fermentation conditions. J. Sci. Ind. Res. 2011, 70, 365-372.

10. Puerari, C.; Magalhães, K.T.; Schwan, R.F. New cocoa pulp-based kefir beverages: Microbiological, chemical composition and sensory analysis. Food Res. Int. 2012, 48, 634-640.

11. Corona, O.; Randazzo, W.; Miceli, A.; Guarcello, R.; Francesca, N.; Erten, H.; Moschetti, G.; Settanni, L. Characterization of kefir-like beverages produced from vegetable juices. LWT-Food Sci. Technol. 2016, 66, 572-581.

12. Randazzo, W.; Corona, O.; Guarcello, R.; Francesca, N.; Germanà, M.A.; Erten, H.; Moschetti, G.; Settanni, L. Development of new non-dairy beverages from Mediterranean fruit juices fermented with water kefir microorganisms. Food Microbiol. 2016, 54, 40-51.

13. Shanmuganayagam, D.; Warner, T.F.; Krueger, C.G.; Reed, J.D.; Folts, J.D. Concord grape juice attenuates platelet aggregation, serum cholesterol and development of atheroma in hypercholesterolemic rabbits. Atherosclerosis 2007,190, 135142. 
14. God, J.M.; Tate, P.; Larcom, L.L. Anticancer effects of four varieties of muscadine grape. J. Med. Food 2007, 10, 54-59.

15. Jung, K.; Wallig, M.; Singletary, K. Purple grape juice inhibits 7,12-dimethylbenz-[a]anthracene (DMBA)-induced rat mammary tumorigenesis and in vivo DMBA-DNA adduct formation. Cancer Lett. 2006, 233, 279-288.

16. Meyer, A.S.; Yi, O.S.; Pearson, D.A.; Waterhouse, A.L.; Frankel, E.N. Inhibition of human low density lipoprotein oxidation in relation to composition of phenolic antioxidants in grapes (Vitis vinifera). J. Agric. Food Chem. 1997, 45, 1638-1643.

17. Rodriguez-Vaquero, M.J.; Alberto, M.R.; Manca-de-Nadra, M.C. Antibacterial effect of phenolic compounds from different wines. Food Cont. 2007, 18, 93-101.

18. Piva, C.R.; Garcia, J.L.L.; Morgan, W. The ideal table grapes for the Spanish market. Rev. Bras. Frutic. 2006, $28,258-261$.

19. Costas, M.; Alonso, E.; Guerra, N.P. Nisin production in realkalized fed-batch cultures in whey with feeding with lactoseor glucose-containing substrates. Appl. Microbiol. Biotechnol. 2016, 100, 7899-7908.

20. Costas, M.; Alonso, E.; Outeiriño, D.; Fajardo, P.; Guerra, N.P. Combination of food wastes for an efficient production of nisin in realkalized fed-batch cultures. Biochem. Eng. J. 2017, 123, 13-23.

21. Cheirsilp, B.; Shimizu, H.; Shioya, S. Enhanced kefiran production of Lactobacillus kefiranofaciens by mixed culture with Saccharomyces cerevisiae. J. Biotechnol. 2003a, 100, 43-53.

22. Oude, S.J.W.H.; Krooneman, J.; Gottschal, J.C.; Spoelstra, S.F.; Faber, F.; Driehuis, F. Anaerobic conversion of lactic acid to acetic acid and 1,2-propanediol by Lactobacillus buchneri. Appl. Environ. Microbiol. 2001, 67, 125-132.

23. Cheirsilp, B.; Shoji, H.; Shimizu, H.; Shioya, S. Interactions between Lactobacillus kefiranofaciens and Saccharomyces cerevisiae in mixed culture for kefiran production. J. Biosci. Bioeng. 2003b, 96, 279-284.

24. Cheirsilp, B.; Radchabut, S. Use of whey lactose from dairy industry for economical kefiran production by Lactobacillus kefiranofaciens in mixed cultures with yeasts. New Biotechnol. 2011, 28, 574-580.

25. Felipe, M.G.; Vieira, D.C.; Vitolo, M.; Silva, S.S.; Roberto, I.C.; Manchilha, I.M. Effect of acetic acid on xylose fermentation to xylitol by Candida guilliermondii. J. Basic Microbiol. 1995, 35, 171-177.

26. Kirtadze, E.; Nutsubidze, N. Metabolic potential of alcoholic fermentation yeasts. Bull. Georgian National Acad. Sci. 2009, 3, 110-116.

27. Mendes, A.; Mendes-Faia, A. The role of yeasts and lactic acid bacteria on the metabolism of organic acids during winemaking. Foods 2020, 9, 1231.

28. Yalçin, S.K.; Özbaş, Z.Y. Determination of growth and glycerol production kinetics of a wine yeast strain Saccharomyces cerevisiae Kalecik 1 in different substrate media. World J. Microbiol. Biotechnol. 2005, 21, 1303-1310.

29. Azhar, S.H.M.; Abdulla, R.; Jambo, S.A.; Marbawi, H.: Gansau, J.A.; Faik, A.A.M.; Rodrigues, K.F. Yeasts in sustainable bioethanol production: a review. Biochem. Biophys. Rep. 2017, 10, 52-61.

30. Lee, Y.K.; Lim, C.Y.; Teng, W.L.; Ouwehand, A.C.; Tuomola, E.M.; Salminen, S. Quantitative approach in the study of adhesion of lactic acid bacteria to intestinal cells and their competition with enterobacteria. Appl. Environ. Microbiol. 2000, $66,3692-3697$.

31. Lonvaud-Funel, A. Lactic acid bacteria in the quality improvement and depreciation of wine. Antonie van Leeuwenhoek, 1999, 76, 317-331.

32. Reale, A.; Di Renzo, T.; Rossi, F.; Zotta, T.; Iacumin, L.; Preziuso, M.; Parente, E.; Sorrentino, E.; Coppol, R. Tolerance of Lactobacillus casei, Lactobacillus paracasei and Lactobacillus rhamnosus strains to stress factors encountered in food processing and in the gastro-intestinal tract. LWT-Food Sci. Technol. 2015, 60, 721-728.

33. Sánchez, C.; Neves, A.R.; Cavalheiro, J.; dos Santos, M.M.; García-Quintáns, N.; López, P.; Santos, H. Contribution of citrate metabolism to the growth of Lactococcus lactis CRL264 at low pH. Appl. Environ. Microbiol. 2008, 74, 1136-1144.

34. Membré, J.M.; Kubaczka, M.; Chéné, C. Combined effects of $\mathrm{pH}$ and sugar on growth rate of Zygosaccharomyces rouxii, a bakery product spoilage yeast. Appl. Environ. Microbiol. 1999, 65, 4921-4925. 
35. Arroyo-López, F.N.; Orlić, S.; Querol, A.; Barrio, E. Effects of temperature, $\mathrm{pH}$ and sugar concentration on the growth parameters of Saccharomyces cerevisiae, S. kudriavzevii and their interspecific hybrid. Int. J. Food Microbiol. 2009, 131, 120-127.

36. Rimada, P.S.; Abraham, A.G. Polysaccharide production by kefir grains during whey fermentation. J. Dairy Res. 2001, 68, 653-661.

37. Poolman, B.; Konings, W.N. Relation of growth of Streptococcus lactis and Streptococcus cremoris to amino acid transport. J. Bacteriol. 1988, 170, 700-707.

38. Fajardo, P.; Rodríguez, I.; Pastrana, L.; Guerra, N.P. Production of a potentially probiotic culture of Lactobacillus casei subsp. casei CECT 4043 in whey. Int. Dairy J. 2008, 18, 1057-1065.

39. Chen, X.H.; Lou, W.Y.; Zong, M.H.; Smith, T.J. Optimization of culture conditions to produce high yields of active Acetobacter sp. CCTCC M209061 cells for anti-Prelog reduction of prochiral ketones. BMC Biotechnol. 2011, 11,110.

40. Liu, J.R.; Lin, C.W. Production of kefir from soymilk with or without added glucose, lactose or sucrose. J.Food Sci. 2000, 65, 716-719.

41. Regulation (EU) No. 1169/2011 of the European Parliament and of the Council of October 25, 2011 on the provision of food information to consumers, amending Regulations (EC) No 1924/2006 and (EC) No 1925/2006 of the European Parliament and of the Council, and repealing Commission Directive 87/250/EEC, Council Directive 90/496/EEC, Commission Directive 1999/10/EC, Directive 2000/13/EC of the European Parliament and of the Council, Commission Directives 2002/67/EC and 2008/5/EC and Commission Regulation (EC) No 608/2004. Off. J. Eur. Union 2011, L 304/18, 34.

42. Viana, R.O.; Teixeira, K.; Braga, R.A.; Dias, D.R.; Schwan, R.F. Fermentation process for production of apple-based kefir vinegar: microbiological, chemical and sensory analysis. Braz. J. Microbiol. 2017, 48, 592-601.

43. Garde, T.; Lorenzo, C.; Carot, J.M.; Esteve, M.D.; Climent, M.D.; Salinas, M.R. Differentiation of barrel-aged wines according to their origin, variety, storage time and enological parameters using fermentation products. Food Cont. 2009, 20, 269-276.

44. Sánchez-Palomo, E.; Izquierdo Cañas, P.M.; Delgado, J.A.; Viñas, M.A.G. Sensory characterization of wines obtained by blending cencibel grapes and minority grape varieties cultivated in La Mancha region. J. Food Qual. 2018, $2018,1-8$.

45. Vilanova, M.; Genisheva, Z.; Graña, M.; Oliveira, J.M. Determination of odorants in varietal wines from international grape cultivars (Vitis vinifera) grown in NW Spain. South African J. Enol. Vitic. 2013, 34, 212-222.

46. Vilanova, M.; Freire, L. Complementary effect of blending on the volatile composition of albariño and loureira white wines (Vitis vinifera L). South African J. Enol. Vitic. 2017, 38, 109-117.

47. Dragone, G.; Mussatto, S.I.; Oliveira, J.M.; Teixeira, J.A. Characterisation of volatile compounds in an alcoholic beverage produced by whey fermentation. Food Chem. 2009, 112, 929-935.

48. Alonso, E., Torrado, A.; Pastrana, L., Orriols, I.; Pérez-Guerra, N. Production and characterization of distilled alcoholic beverages obtained by solid-state fermentation of black mulberry (Morus nigra L.) and black currant (Ribes nigrum L.). J. Agric. Food Chem. 2010, 58, 2529-2535.

49. Cortés, S.; de la Peña, M.L.G.; Gómez, E.F. Volatile composition and sensory characters of commercial Galician orujo spirits. J. Agric. Food Chem. 2005, 53, 6759-6765.

50. Garcia-Carpintero, E.G.; Sanchez-Palomo, E.; Gallego, M.A.G.; Gonzalez-Viñas, M.A. Volatile and sensory characterization of red wines from cv. Moravia Agriaminority grape variety cultivated in La Mancha region over five consecutive vintages. Food Res. Int. 2011, 44, 1549-1560.

51. Cortés, S.; Rodriguez, R.; Domínguez, J.M.; Díaz, E. Impact odorants and sensory profile of young red wines from four Galician (NW of Spain) traditional cultivars. J. Inst. Brew. 2015, 121, 628-635.

52. Ferreira, V.; Culleré, L.; López, R.; Cacho, J. Determination of important odor-active aldehydes of wine through gas chromatography-mass spectrometry of their O-(2,3,4,5,6-pentafluorobenzyl)oximes formed directly in the solid phase extraction cartridge used for selective isolation. J. Chromatogr. A, 2004, 1028, 339-345. 
53. Verma, D.K.; Srivastav, P.P. A paradigm of volatile aroma compounds in rice and their product with extraction and identification methods: A comprehensive review. Food Res. Int. 2020, 130, 108924.

54. Duarte, W.F.; Dias, D.R.; Oliveira, J.M.; Teixeira, J.A.; de Almeida e Silva, J.B.; Schwan, Ferreira, V. Volatile aroma compounds and wine sensory attributes. In Managing wine quality. Viticulture and wine quality; Reynolds, A.G., Ed.; CRC Press, Taylor \& Francis Group LLC: Boston, USA, 2010; Vol. 1, pp. 3-28.

55. Perestrelo, R.; Fernandes, A.; Albuquerque, F.F.; Marques, J.C.; Câmara, J.S. Analytical characterization of the aroma of Tinta Negra Mole red wine: Identification of the main odorants compounds. Anal. Chim. Acta, 2006, 563, 154-164.

56. Ferreira, V. Volatile aroma compounds and wine sensory attributes. In Managing wine quality. Viticulture and wine quality; Reynolds, A.G., Ed.; CRC Press, Taylor \& Francis Group LLC: Boston, USA, 2010; Vol. 1, pp. 3-28.

57. van Gemert, L.J. Odour thresholds. Compilations of odour threshold values in air, water and other media. Edition no. 2; Oliemans Punter \& Partners BV: Utrecht, The Netherlands, 2011.

58. Pino, J.A.; Quijano, C.E. Study of the volatile compounds from plum (Prunus domestica L. cv. Horvin) and estimation of their contribution to the fruit aroma. Ciência e Tecnologia de Alimentos 2012, 32, 76-83.

59. Burdock, G.A. Fenaroli's Handbook of flavour ingredients, edition no. 6; CRC Press, Taylor \& Francis Group LLC: Boca Raton, Florida, USA, 2010.

60. Bingham, E.; Cohrssen, B.; Powell, C.H. Patty's Toxicology, edition no. 5; John Wiley \& Sons: New York, USA, 2001; Vol. no. 1-9, pp. 6:318.

61. Samappito, S.; Butkhup, L. Effect of skin contact treatments on the aroma profile and chemical components of mulberry (Morus alba Linn.) wines. Afr. J. Food Sci. 2010, 4, 052-061.

62. Mei, J.; Liu, F.; Fang, S.; Lan, W.; Xie, J. High-CO2 modified atmosphere packaging with superchilling $\left(-1.3{ }^{\circ} \mathrm{C}\right)$ inhibit biochemical and flavor changes in turbot (Scophthalmus maximus) during storage. Molecules 2020, $25,2826$.

63. Czerny, M.; Christlbauer, M.; Christlbauer, M.; Fischer, A.; Granvogl, M.; Hammer, M.; Hartl, C.; Moran N.; Schieberle, P. Re-investigation on odour thresholds of key food aroma compounds and development of an aroma language based on odour qualities of defined aqueous odorant solutions. Eur. Food Res. Technol. 2008, 228, 265-273.

64. de Sousa, M.; Narain, N.; do Socorro, M.; Nunes, M.L. Volatile compounds and descriptive odor attributes in umbu (Spondias tuberosa) fruits during maturation. Food Res. Int. 2011, 44, 1919-1926.

65. Arcari, S.G.; Caliari, V.; Sganzerla, M.; Godoy, H.T. Volatile composition of Merlot red wine and its contribution to the aroma: optimization and validation of analytical method. Talanta 2017, 174, 752-766.

66. Welke, J. E.; Zanus, M.; Lazzarotto, M., Zini C.A. Quantitative analysis of headspace volatile compounds using comprehensive two-dimensional gas chromatography and their contribution to the aroma of Chardonnay wine. Food Res. Int. 2014, 59, 85-99.

67. Liu, S. Q.; Holland, R.; Crow, V.L. Esters and their biosynthesis in fermented dairy products: a review. Int. Dairy J. 2004, 14, 923-945.

68. Zhao, P.; Gao, J.; Qian, M.; Li, H. Characterization of the key aroma compounds in chinese syrah wine by gas 
chromatography-olfactometry-mass spectrometry and aroma reconstitution studies. Molecules 2017, $22,1045$.

69. Bowen, A.J.; Reynolds, A.G. Odor potency of aroma compounds in Riesling and Vidal blanc table wines and icewines by gas chromatography-olfactometry-mass spectrometry. J. Agric. Food Chem. 2012, 60, 2874-2883.

70. Walsh, A.M.; Crispie, F.; Kilcawley, K.; O’Sullivan, O.; O'Sullivan, M.G.; Claesson, M.J.; Cotter, P.D. Microbial succession and flavor production in the fermented dairy beverage kefir. MSystems 2016, 1, e00052-16.

71. Zhai, X.; Granvogl, M. Characterization of the key aroma compounds in two differently dried Toona sinensis (A. Juss.) Roem. by means of the molecular sensory science concept. J. Agric. Food Chem. 2019, 67, 9885-9894.

72. Brennand, C.P.; Ha, J.K.; Lindsay, R.C. Aroma properties and thresholds of some branched-chain and other minor volatile fatty acids occurring in milkfat and meat lipids. J. Sens. Stud., 1989, 4, 105-120.

73. Reale, A.; Di Renzo, T.; Boscaino, F.; Nazzaro, F.; Fratianni, F.; Aponte, M. Lactic acid bacteria biota and aroma profile of Italian traditional sourdoughs from the irpinian area in Italy. Front. Microbiol. 2019, 10: 1621.

74. Barron, L.J.R.; Redondo, Y.; Aramburu, M.; Perez-Elortondo, F.J.; Albisu, M.; Najera, A.I.; de Renobales, M. Variations in volatile compounds and flavor in Idiazabal cheese manufactured from ewe's milk in farmhouse and factory. J. Sci. Food. Agric. 2005, 85, 1660-1671.

75. Dertli, E.; Çon, A.H. Microbial diversity of traditional kefir grains and their role on kefir aroma. LWT - Food Sci. Technol. $2017,85,151 \mathrm{e} 157$.

76. Prager, J.C. Environmental Contaminant Reference Databook; Prager, J.C., Ed.; Van Nostrand Reinhold: Florence, Kentucky, USA, 1995; Vol. no. 1.

77. Agregán-Pérez,R.; Alonso-González, E.; Mejuto, J.C.; Pérez-Guerra, N. Production of a Potentially Probiotic Product for Animal Feed and Evaluation of Some of Its Probiotic Properties. Int. J. Mol. Sci.2021, 22, 10004. https://doi.org/ $10.3390 / \mathrm{ijms} 221810004$

78. Jagatić, A.M.; Preiner, D.; Tomaz, I.; Jeromel, A. Volatile profile characterization of Croatian commercial sparkling wines. Molecules 2020, 25, 4349. 